\title{
EENIGE KOLONIALE VRAAGSTUKKEN VAN DEN DAG.
}

\author{
Mr. N. G. Pierson, Koloniale Politiek, \\ Amsterdam bij P. N. van Kampen 1877.
}

Aan het slot van ons vorig stuk $\left(^{*}\right)$ zeiden wij, dat eene nadere ontwikkeling van het kultuurstelsel onnoodig scheen, omdat het algemeen bekend is. Bij nadere overweging is ' $t$ ons echter gebleken, dat, in verband met de koloniale rraagstukken, die wij ons voorgenomen hebben te behandelen, het zijne goede zijde hebben kan, de gevolgen en resultaten van dat stelsel in hoofdtrekken te overzien. Daarvoor is het noodig ook een kort woord over het stelsel zelf te zeggen.

De koffie was eigenlijk het eenige product dat van gouvernemen'swoge op de Nederlandsche markt werd gebracht. Wel bestonden eenige particuliere ondernemingen voor suiker (b. v. in de Bataviaasche Ommelanden) en indigo, en waren eenige proeven genomen met thee-, zijde-, cochenille en tabakkultures, maar terwijl de laatsten nog geen artikel van uitvoer opleverden, waren die van suiker en indigo in kwijnenden toestand. Van den Bosch begreep, dat, wanneer het gouvernement zelf die producten liet verbouwen, het door de kracht van het gezag en van het grooter kapitaal, en bovendien gebruik makende van de werkkrachten der inlandsche bevolking, ook met meer vooruitzicht op winst, dan zulks voor particulieren mogelijk was, zou kunnen werken, en dat de daardoor te verkrijgen winsten den benarden financieelen nood van het vaderland zouden kunnen te hulp komen ( $\dagger$ ).

Aanvankelijk geschiedde de bewerking van sommige grondstoffen, als indigo, thee, cochenille, kaneel, zijde, tabak in gouverne-

(*) Zie Economist 1878, blz. 803 en volgende.

( $\uparrow$ " Het ingevoerde stelsel van kultuur (zoo drukt vain den Bosch aich uit) heeft de strekking om het gouvernement in stat te stellen over honderd dujzenden van handeu te doen beschikken. ". Mr. P. Mijer, J. C. Baul geschetst. blz. 411 . ECoN. 1879. 
mentsfabrieken. Voor de suiker werden contracten aangeboden, d. i. het gouvernement verstrekte aan de ondernemers een zeker voorschot in geld tot oprichting der fabriek en voorloopig bedrijfskapitaal; zij kregen echter de toezegging, dat de bevolking het riet zou planten en tot rijpheid brengen, voor welken arbeid een gering plantloon zou worden betaalc. Daarentegen moesten zij zich verbinden, om zoo lang het contract duurde, eene zekere hoeveelheid van het bewerkte product tegen een bij hetzelfde contract vastgestelden prijs aan het gouvernement te leveren. Hetgeen zij meer produceerden konden zij voor eigen rekening verkoopen.

Weldra zag men in, dat de bewerking van indigo van gouvernementswege in diens fabrieken minder voordeelig was, en men sloeg toen daarvoor denzelfden weg in als voor de suiker, nl. uitgifte van contracten. De overige producten zijn voortdurend van gouvernementswege bewerkt.

Wat de koffiekultuur betreft, zij werd uitgebreid; behalve de koffie die reeds vóór dien tijd in sommige gewesten, zooals de Preanger, Buitenzorg, Banjoewangie, enz. voor rekening van het gouvernement werd geteeld, moest voortaan alle koffie, die aan het betalen van landrente onderworpen was, aan het gouvernement worden geleverd (*). Bovendien werden op breede schaal nieuwe tuinen aangelegd, en werden de dessa's gedesigneerd - de uitdrukking is karakteristiek - voor den aanleg en het onderhoud. De belooning die de bevolking ontving, was - na aftrek van $\frac{2}{5}$ voor landrenten en $f 2,50$ voor transportkosten - iets meer dan $f 10$ per pikol van 125 Amst. pond.

Om al deze maatregelen met eenig goed resultaat in te voeren, was reeds bij het Reg. Reglement van 19 Januari 1830 , dat van den Bosch had medegekregen, niet alleen het verbod van Commissarissen-Generaal, om contracten te sluiten met geheele dessa's $(\dagger)$, opgeheven, maar werd ook als beginsel vastgesteld, dat alle gronden op Java, over zoover zij vroeger niet reeds vervreemd waren, als eigendom van den lande te beschouwen waren, en dat zij dessa's wijze aan de bevolking zouden worden verhuurd door middel van overeenkomsten met de hoofden en oudsten, onder zoodanige

(*) Natnurijk was daarvan uitgezonderd de koftie van particuliere landen, terwijl ook voor die, welke de Vorstenlanden opbrachten, bijzondere regelingen zouden worden gemaakt.

(†) Zie Écon. 1878, blz. 816. 
bepalingen, als telkens in de huurcedels of piagems zouden worden uitgedrukt $(*)$.

Bovendien, wilde het stelsel inderdaad de verwachte vruchten opleveren, het geheel binnenlandsch bestuur moest er in betrokken worden. Hoofden van gewestelijk bestuur, de inlandsche hoofden allen moesten er bij geinteresseerd worden. Daarvoor' zou de prikkel van eigenbelang werken. Alan de Nederlandsche ambtenaren' en inlandsche hoofden - van den Regent af tot het dorpshoofd toe - werden geldelijke voordeelen voorgespiegeld in den vorm van kultuurprocenten. Naármate dus de kúltuur van een der bovengenoemde producten toenam, nair die mate klommen ook de inkomsten van de ambtenaren en hoofden. Maar vocral de Iaatstgenoemden moesten de handlangers worden van hèt gouvernement; zij toch oefenden veel meer invloed uit op de bevollking, dan de heeren ambtenaren. Was door Commissarissen-Generabl het ambtelijk landbezit afgeschaft, wegens de drukkende last voor de bevolking, en de aanleiding, die het gaf tot willekeur en knevelarij ( $\dagger$ ), thans werd het weder hersteld. Merkwaardig is 't echter, dat het Ind. Staatsblad van dat herstel geen gewag maakt; het werd bevolen bij een geheim Koninkl. besluit van' 12 Januari 1832 Lit $\mathrm{Y}(\S)$.

Bij al de schitterende vooruitzichten, die van het stelsel van den gener. van den Bosch werden voorgespiegeld, en niettegenstaande de verrassende uitkomsten', die ondervonden werden $\left({ }^{* *}\right)$,

(*) Zie Reg. Regl. van 19 Jan. 1830 artt. 74 in 75 . Vergelijk obk art. 116 , luidende:

"Het is aan geene der ambtenaren, Europeesche of inlandsche; noch ann iemand anders geoorloofd, om aau andereu de beschikking over de grouden en inwoners der dessa's af te stan.

- Echter zal aan de ingezetenen gelegenheịd worden gegeven, om tot voortzeiting vau nuttige onderueningen overeeukomsten aan te gaan met de ondsten en voornaamsten der dessa's, zoowel tot het bebcuweu van gronden en het levereu van bijzondere voortbrengselen als tot bet verleenen van persoonlijke diensten. De wijze waarop dit een en ander kan geschieden, wordt vau tijd tot tijd door deu G.-Gen. in Rade bepaald, naar het beginsel om de inlandsche bevolking tegen alle willekenr te beschemmen (NB!) doch tevens on, in het algemeen belang aan nuttige bedrijven de noodige handen te verschaffen tegen een matig loon."

$(\dagger)$ Zie boven blz. 812 .

(\$) Zie van Deventer, II, blz. 358 Cf. ordomnatie van 5 Janudri 1866 (Iud. Stbl. no. 3) art. 1, ur. 1 "met intrekking van bet Kon. Besl. van I2 Jan. 1832 Lit. Y geheim ", euz.

(**) De waarde der handels-producteu voor den uitvoer bestemd was in het tijdvak 
vond het aanvankelijk weinig sympathie noch in Indië, noch hier te lande $(*)$. Ook in den Raad van Indië waren leden, die niet eenstemmig met den Gouverneur-Generaal dachten. Vooral was 't Mr. P. Merkus, die met kracht en talent zich tegen het stelsel verklaarde. Maar voor alles wist men raad. In Nederland bekommerde men zich niet om de oordeelvellingen $(\dagger)$; en op het beklag van den Generaal van den Bosch over de tegenwerking in den Raad van Indië, werd uit den Haag aan dat hoogste regeeringscollegie eene scherpe berisping gegeven, en aan de oppositie het zwijgen opgelegd (§); en ten einde den Landvoogd in de gelegenheid te stellen ongehinderd zijne plannen ten uitvoer te brengen, werd hij bij open brief des Konings van 17 Januari 1832 - dus eenige dagen na het bovenvermelde geheim besluit van 12 Januari - tot Commissaris-Generaal benoemd, en dus boven het Regeer. Reglem. gesteld, en hem de macht gegeven om ambtenaren aan to stellen en te ontslaan zonder eenig onderscheid van rang of stand. Dit laatste doelde blijkbaar op de leden van den Raad van Indië (**).

Ook onder de industrieelen schenen de vooruitzichten niet zoo schitterend. De regeering dwong soms contracten op; de heer Fransen van de Putte heeft in zijne brochure: de regeling en de uillesteding van de suikercontracten op Java de anecdote verhaald, dat de resident van Passoeroean den $L^{t}$ Chinees tot het aangaan van een contract heeft bewogen door hem te dreigen, dat hij anders zijn vader niet in den rang van Kapitein-Chinees zou opvolgen. Zelfs een Bengaleesche kok werd tot suikercontractant bevorderd ( $\dagger$ ).

De herhaalde aanmaningen uit het moederland naar grootere

van 1830-1834 van acht tot twintig millioen geklommen. Mr. P. Mijer, J. C. Baud geschetst, 1. 1. 418.

$\left({ }^{*}\right)$ "De algemeene opinie is er tegen gestemd", schreef Baud uit Indië den 30 Aug. 1833 aau vau der Capellen. Zie Mijer 1.1. blz. 398. “Onze vriend van den Bosch zal een potje te vuur vinden. Zijn systema van kultuur, boe productief, viudt hier, dat kunt gij uiet begrijpen, eene af keuring en tegenstand zouder weêrga", schreef Brocx, Secret. Gener. van het Dept. van Kolon,, in 1834 aan Baud. Zie Mijer 1.1. 415.

$(\dagger)$ Zie denzelfden brief van Brocx aan Band, bij Mijer 1.1.

(\$) Dit geschiedde bij het zelfde geheim besluit vau 12 Januari 1832 , waarvan wij boven melding mankten. Zie van Deventer, II, blz. 359 en volg.

(**) Vau Deveuter, 1.1.361.

(†) Pierson, blz. 110. 
remises, gepaard met den benarden toestand der financiën ten gevolge van den opstand van Belgie, dwongen om met de toepassing van het stelsel al verder en verder te gaan. "Ook de te groote ijver van eenigen moet worden bewaakt, voor zoover die namelijk de strekking heeft, om van den Javaan meer te vorderen, dan hij gaarne verricht," had van den Bosch gezegd (*); doch èn de dringende eischen uit Nederland èn het eigen belang der ambtenaren hadden die vermaningen verijdeld. Met een ongehoord cynisme werd in 1842 de instructie van den G.-Gener. in dien zin aangevuld, dat niet alleen den Landvoogd was opgedragen, om al zijne zorg aan de vermeerdering van batige saldos te wijden, maar ook elke uitgave, die nict ruste op onvermijdelijke noodzakelijkheid, af te wijzen $(\dagger)$.

Had men beloofd geene landrente te heffen van die dessa's, die het $\frac{1}{5}$ harer gronden ter bebouwing van producten voor de Europesche markt hadden afgestaan, men vergat die belofte, en eischte als van ouds de landrente ook van de overige gronden; was aanvankelijk bepaald, dat de inlander kon volstaan met het gewas tot rijpheid te brengen, men dwong hem later ook het naar de fabriek te brengen, en in de fabriek te werken; men vergenoegde zich niet met het $\frac{1}{3}$, men beschikte over al de gronden; was de inlander de keuze gelaten, om of op de oude wijze landrente te betalen ò om op de voorschrevene wijze voor het gouvernement te arbeiden, de keuze werd niet gelaten; en al had men bij de invoering van het stelsel luid doen klinken, dat geen dwang zou worden opgelegd, het stelsel moest noodwendig tot dwang leiden, wilde men bevredigende resultaten hebben.

Het besluit van den Gouverneur-Generaal ad interim J. C. Baud van 28 Maart 1834 (§), zegt dat het kultuurstelsel drieledige strekking had, nl. om de O.-Ind. bezittingen in staat te stellen zich te kwijten van hare-geldelijke verplichtingen jegens het moederland; om aan den nationalen handel en schecpvaart een nieuw leven te geven, en eindelijk, om de handelsproducten, die met dat doel werden voortgebracht, op de voor het gouvernement minst kostbare, en op de voor den inlander minst bezwarende, en met de aloude instellingen (adat) meest overeenkomende wijze, te verkrijgen.

(*) Mijer, 1.1. 413 .

(f) Pierson, blz. 121 in notis.

(j) Zije Ind. Stbl, 1834 no, 22, 
Laat ons, de gevolgen van het stelsel aan de overweging van dat besluit tootsende, thans kortelijk nagaan, welke zijn invloed is geweest op den inlander en den inlandschen maatschappelijken toestand; welke op de handels- on ondernemingsgeest in het algemeen, en welke op den financieelen toestand van ons Vaderland?

Ten gevolge van het kultuurstelsel was het gouvernement planter, koopman on industrieel tevens $\left(^{*}\right)$. Als zoodanig moest het voortdurend bedacht zijn op lage arbeidsloonen, want daarin lag de winst gelegen, dat men nergens zoo goedkoop zou kunnen produceren. Terwijl vrije arbeid ten opzichte van de loonen door de algemeene mededinging en door de economische wet van navraag en aanbod beheerscht wordt, kan eene regeering, die in de plaats yan het individu zelve industrieel wordt, zich boven den algemeonen regel stellen. De loonen bleven dan ook voortdurend zoo laag, dat zij onmogelijk konden bijdragen, om de bevolking tot den staat van welvaren op te voeren. Maar een ernstiger grief tegen het stelsel is, dat het gouvernement daardoor te kort moest schieten in zijne verplichting om de inlandsche bevolking te beschermen tegenover wien dan ook - en dus zoowel tegenover de Nederl. ambtenaren als tegenover hare eigene hoofden. Door deze geldelijk belang te doen stellen in de resultaten van het stelsel, gaf de fegeering de bevolking prijs aan de grofste willekeur en dwang. „Hoe kon," vraagt de heer Pịerson, „de regeering met nadruk van de hoofden eischen de bescherming der bevolking als hun eerste en duurste plicht te beschouwen, terwijl zij. zelve dien plicht verzaakte? Hoe verlangen, dat zij gewillig luisterden naar billijke klachten, die tot hen kwamen, nu ook zij om financieele redenen vaak de ooren daaryoor sluiten moest? Hoe verhinderen dat zij zich niet door baatzucht lieten beheerschen, nu zij dagelijks., zij 't danjook ten voordeele van de Nederlandsche schatkist, van baatzucht het voorbeeld gaf? Het kan niet anders, of de algemeene geest, die het Opperbestuur beheerschte, moest ook de hoofden beheerschen van den regent af tot het kleinste deşahoofd toè. Is winstbejag het doel waarmede eene kolonie wondt bestuurd, dan zullen de beste reglementen, de schoonste kahinetscirculaires niet verhinderen, dat. de bevolking wordt gekneveld" (†). Ook op

$\left({ }^{*}\right)$ "Ecn stelsel van bestuur, dat de regeering hoe langer hoe meer tot den bijua eenigen kultivateur en opkooper der voornaamste hąndelsprodụcten paakt." Mijer 1.1. 411.

(†) Pierşon, bla, 119. 
het personeel der Nederlandsche ambtenaren werkte het kultuurstelsel demoraliseerend; niet alleen hunne inkomsten, maar ook hunne carrière hing af van hunnen minderen of meerderen ijver in de bevordering der goede resultaten der verschillende ondernemingen. „Het kultuurstelsel moest gehandhaafd worden in al zijne gestrengheid. De middelen die daartoe werden aangewend, zijn nog niet alle openbaar geworden; in 1841 is dienaangaande van wege het Indisch bestuur eene enquête ingesteld bij de Residenten, doch de ontvangen antwoorden liggen nog begraven in het arohief te Batavia" (*). Doch wat daaruit openbaar is geworden, is genoeg om den staf te breken over een stelsel, dat tot zulke middelen de toovlucht moest nemen. Dessa's werden bedreigd met het verlies hunner rijstvelden, indien zij weigerden suikerriet te planten; zij die zich beklaagden over de te geringe betaling, werden tot dwangarbeid veroordeeld; men dwong somtijds dessa's indigo en suiker te planten op de gronden eener andere dessa, omdat men vreesde, dat zij de hunne te veel zouden ontzien; men heeft koffietrinen aangelegd op gronden, die reeds toebereid waren voor den verbouw van eigene voedingsmiddelen; er zijn voorbeelden, dat de bevolking met zweepslagen naar de koffietuinen moest gejaagd worden; bij de uitbreiding der koffiekultuur werden veelal tuinen aangelegd op verren afstand der dessa's; de gouvernementspakhuizen, waar de bevolking de door haar geplukte en bereide koffie moest brengen, lagen eveneens dikwijls op verren afstand van de plaats der inwoning; dáar moest ieder, na den soms verren gang, wachten op zfjne beurt om de koffie af te leveren, en al dien tijd moest hij op eigene kesten leven; er werd suiker geplant op velden, of er werden koffietuinen aangelegd op gronden, die later bleken voor een en ander ongeschikt te zijn; de bevolking had al den last er van gehad, en de vergoeding was schraal - zoo er al vergoeding werd gegeven.... Doch waartoe meer, om te bewijzen, dat zoo het al waar was, wat de overweging van het bovengenoemd besluit van den Gouverneur-Generaal van 20 Maart 1834 zeide, dat de handelsproducten op eene voor het gouvernement mist kostbare wijze werden verkregen - het was geheel onjuist dat zij verkregen werden op de voor den Inlander minst bezwarende wijze.

De gevolgen bleven dan ook niet achter. Op verscheidene plaatsen volksverloop - alleen uit Japara verhuisden 2118

(*) Pierson, blz. 122, 
personen - elders hadden oproerige bewegingen plaats, omdat de druk te zwaar was, en men zich trachtte te verzetten. Ook achteruitgang der rijstteelt, het voornaamste voedingsmiddel was het treurig gevolg er van, òf omdat de velden te laat aan de bevolking werden teruggegeven, waardoor zij verplicht werd rijst te verbouwen, die slechts 3 à 4 maanden noodig heeft om rijp te worden, terwijl de betere kwaliteiten 6 à 8 maanden behoeft om geoogst te worden, òf omdat de gronden door het gouvernement in beslag waren genomen, ò omdat de gronden zoo uitgemergeld waren, dat zij ongeschikt waren voor dadelijke wederbebouwing $\left({ }^{*}\right)$.

Was het kultuurstelsel dus geen zegen voor het individu. Ook zijn invloed op den maatschappelijken toestand der bevolking was ongunstig, en 't is ook hier onjuist wat de overweging van het besluit van 28 Maart 1834 zegt, dat nl. het kultuurstelsel het meest overeenkomt met de aloude instellingen der bevolking

Vooreerst de dorpsinstellingen zijn bedorven. Reeds in ons vorig stuk hebben wij gesproken over de dorpshoofden, die oorspronkelijk rechtstreeks gekozen werden door de ingezetenen $(\dagger)$; de vrijheid der dessabevolking moest in geene deele belemmerd worden; het dessahoofd moest de vertegenwoordiger zijn van de ingezetenen, ook zelfs tegenover het gouvernement. Maar sedert de invoering van het kultuurstelsel kon geen zelfstandig vertegenwoordiger van de dessa geduld worden; het hoofd moest even als de regent en het districtshoofd - de handlanger worden van het gouvernement. Zij, die te veel de rechten der ingezetenen trachtten te verdedigden, werden ontslagen, en een meer gedienstig man in zijne plaats benoemd. Ging 't minder goed met de suikerfabriek of $d \theta$ koffietuinen, het hoofd werd er aansprakelijk voor gesteld, met blokarrest of zelfs met rottingslagen gestraft (§). Met den val van den vertegenwoordiger der dessa, viel ook de vrijheid der bevolking. Werden vroeger de hoofden gekozen uit de aristocratie der dessa, nu het gouvernement menschen noodig

$\left(^{*}\right)$ Merkwaardig is ook het getuigenis, dat de $\mathrm{Mem}$. v. T. op het $w$. o. betrekkelijk de kultuur-ondernemingen op Java van den minister Uhlenbeck (zitting der 2e Kamer 1861/62) gal van de overdrijving van het kultuurstelsel.

(†) Zie Econ. 1878, blz. 815 .

(\$) "Wegens voortdurende nalatigheid in de koffie- en suikertuinen" heette het. Zie van Deventer, I, 418 De rottingslagen werd sorus tot een maximum van 30 slagen en in de koffie- en stikertuinen gegeven, alzoo in strijd met de gewoonte, dat zij niet in het openbaar geschieden mochten. 
had, die 't met de uitvoering der kultuurmaatregelen belasten moest, kwam de betrekking in handen ${ }_{n}$ van lieden van de laagste volksklasse" - het zijn de woorden van eenen voormaligen Directeur der kultures, die door den heer Pierson worden aangehaald: Oppassers en staljongens van inlandsche en Europeesche ambtenaren werden tot dessahoofden benoemd $\left({ }^{*}\right)$.

Ten tweede, het kultuurstelsel heeft niet alleen de conversio van het communaal in het individueel grondbezit in den weg gestaan, maar ook het individueel grondbèzit, waar het bestond vernietigd. Immers het ligt in den aard der zaak, dat het gouvernement er belang bij had, om over uitgestrekte velden te kunnen beschikken. Ware het individueel bezit aangewakkerd, de regeering had onmogelijk de kultures kunnen uitbreiden; nu kon het eenvoudig op de communale gronden der dessa beslag leggen; immers zij werden als eigendom van den Staat beschouwd, waarover het Gouvernement naar willekeur kon beschikken Reeds in de Memorie v. T. op de kultuurwet des heeren Fransen van de Putte werd gezegd: waren de gouvernements kultures niet ingevoerd, dan zouden in 'de geheele residentie (Cheribon) op kleine uitzonderingen na, de 'sawah's in handen van vaste bezitters zijn." En zeer onlangs werd hetzelfde beweerd door den Minister van Koloniën, Alting Mees: „individueel grondbezit.... was eigenlijk op Java de oorspronkelijke toestand, maar nadat de heeren- en kultuurdiensten, en vooral de suikerkultuur er zijn ingevoerd, is door sommige residenten.... het communaal grondbezit ingevoerd geworden. Het bestond niet, maar is van regeeringswege tot stand gebracht" $(\dagger)$. Later legde dezelfde minister de verklaring af ${ }_{n}$ dat overal, waar individueel bezit heeft bestaan het communaal bezit daarvoor is in de plaats getreden, ten gevolge van het heerendiensten- on kultuurstelsel" (\$). Zoo wordt ook in het Rapport over de agarische angelegenheden van den heer Levysohn Norman gezegd: ,Vrij algemeen werd erkend - en op sommige plaatsen was de herinnering nog levendig aan het tijdstip, waarop, en den persoon, waaronder zulks had plaats gevonden - dat het communaal bezit op Java zijn oorsprong had in het landrentenstelsel in den vermeerderden druk der heerendiensten en in de op hoog gezag ingevoerde kultures, bij wier in- en opvoering men dit het

(*) Pierson, blz. 141.

(†) Hand. 2e Kamer, zitting 1876/L877, blz, 254,

(§) Ibid. blz. 748 , 
rationeelete vond om lusten en lasten gelijkelijk om te slaan. Als een bewijs dat vooral de dwangkultures tot dien willekeurigen greep in het grondbezit van den inlander het hare hadden toegebracht, werd aangevoerd, dat bij intrekking der kultures de bevolking van zelve weer geheel of ten deele tot den ouden toestand is overgegaan" $(*)$. En hoe men soms te werk ging, om zelfs voor het vervolg alle bewijzen van vroeger bestaand individueel grondbezit te does verdwijnen, bewijst hetgeen de Regent in het Cheribonsche district Gegisik zich veroorloofde, toen hij de registers en eigendomsbewijzen deed verbranden $(\dagger)$.

Eindelijk daar, waar kultuur- en heerendiensten drukkend waren, hebben dessa's stelselmatig en naar gestreefd het aantal deelhebbers te vermeerderen, ten einde de druk der lasten te verdeelen en dus minder zwaar te maken. Maar daardoor zijn in sommige streken de aandeelen in de communale gronden, ten gevolge waarvan het middel, om in het levensonderhoud to voorzien, ook zeer verminderd, tot $\frac{1}{16}$ bouw ingekrompen. Dit heeft zelfs nu nog plaats, en zou men zelfs gaarne zich nog eenig grondverlies getroosten, als daardoor nieuwe werkkracht gewonnen kon worden (§).

Het bovenaangehaald Besluit van den Gouverneur-Generaal van den 28 Maart 1834 beroept zich op den adat. De adat? een groot woord. Men maakte in dien tijd den adat bij prentah, bevel, van het Gouvernement. Doch wanneer de toenmalige Gouverneur-Generaal J. C. Baud zich op den adat beroept, om aan het kultuurstelsel een glimp van wettigheid te geven, dan veroorlooven wij ons te beroepen op de woorden van denzelfden J. C. Baud, in 1853 - en dus angeveer een twintigtal jaren later - vitgesproken: "dat daardoor aan de Javaansche maatschappij een gedeeltelijk reeds volbrachte omwenteling is voorbereid, die noch met de eischen der rechtvaardigheid, noch met die van het Staatsbelang kan worden overeengebracht" (*).

Welken invloed heeft het kultuurstelsel uitgeoefend op de ontwikkeling van den handel- en industriegeest? Men zou het met een woord kunnen uitdrukken, het heeft beide verlamd! Voor-

(*) Blz. 51 en volg.

$(\dagger)$ Redev. van den minister Alting Mees (Hand. 2e Kamer 1876/1877 blz. 749);

Pierson, blz. 145; van Deventer, III. blz. 94.

(\$) Levyssohn Norman, Rapport, blz. 52,

(**) Pierson, blz. 140. 
eerst het gouvernement kon geene concurrentie dulden; het particulier initiatief werd moedwillig, met voorbedachte rade tegengegaan en onderdrukt; met het kultuurstelsel was bv. uitgifte van gronden aan particulieren eene onmogelijkheid, want daardoor zou eene mededinging ten nadeele van het gouvernement ontstaan; men denke slechts aan de hoogere dagloonen, welke particulieren zouden uitlooven $(*)$. Bovendien, ofschoon de regeering onmogelijk dadelijk over al de gronden kon beschikken, zij moest er op bedacht zijn, dat zij later ze wel gebruiken konde, en zij konde ze dus niet uit hare handen geven. Eindelijk werkte het stelsel daarom ook demoraliseerend, omdat eensdeels bij de gemakkelijkheid om winsten te maken, de energie voor vrije industrie allen prikkel miste, anderdeels tengevolge van speculatiën om maar contracten aantegaan zonder de vereischte kennis, verscheidene ondernemingen te gronde gingen, waardoor niet alleen millioenen, maar ook het vertrouwen te loor gingen. Zelfs de Handelmaatschappij, dat machtig lichaam, dat bij de oprichting zich ten doel stelde, de bevordering van handel en scheepvaart enz. in Nederland en de overzeesche bezittingen, en zulks door het uitbreiden der bestaande handelsbetrekkingen en door het openen van nieuwe wegen van den handel, heeft zich aan den demoraliseerenden invloed van het consignatiestelsel, zoo nauw verbonden met het kultuurstelsel, niet kunnen onttrekken; in plaats van den geest te scherpen naar nieuwe en andere bronnen van handel elders, heeft zij aan den meer gemakkelijken handel op Java de voorkeur gegeven, die haar voortdurend van de noodige en voordeelige retourvrachten verzekerde.

Heeft het kultuurstelsel zich op den duur staande kunnen houden? O neen! Weldra ontdekte men òf dat de op hoog gezag ingevoerde kultures niet dat voordeel opleverden, dat men zieh voorgespiegeld had, integendeel dat het verlies grooter was dan het voordeel, òf dat zij voor de bevolking inderdaad te bezwarend waren ( $\dagger$ ). De zijde-, de indigo- en de kaneelkultuur, als ook de

(*) In November 1838 schreef hij ( $\vee$. d. Bosch) naar Indie: " " dat het stelsel y:an cultures geacht werd zịch bezwaarlijk te verdragen met uitgifte van land, waardopr buiten den kring van het dornsgezag een behoefte aan arbeiders zou ont staan, die reẹlal niẹt anders bẹredigd zou kunnen worden dan ten kasto der

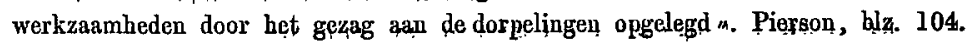

(†) Bij de Mem. v. T. op de kultuurwet van den Minister Fransen v. d. Putte 
cochenilleteelt werden ingetrokken; de gouvernements theetuinen aan particulieren verpacht; de tabak aan de particuliere industrie overgelaten. Dit alles geschiedde, zoo wij ons niet vergissen in of omtrent 1865. De verplichte teelt der specerijen in de Molukken was reods een 10tal jaren vroeger opgeheven. Er bleef niets over dan de suiker, omdat men daarbij door de contracten gebonden was, en de op hoog gezag aangelegde koffietuinen. Deze geweldige inkrimping der kultures was wel het beste bewijs van de onmogelijkheid om het stelsel in zijn geheele omvang te bestendigen, en van den kunstmatigen toestand, die op den duur niet kon blijven bestaan.

En nu de financieele uitkomsten. Wij nemen hier de berekeningen van den heer Pierson, als de bevoegde beoordeelaar er van, over. Volgens hem is het totaal der winsten van 1840 tot 1874 (na aftrek der verliezen) ruim $f 781$ millioen geweest; hiervan komt $f 639$ millioen alleen van de koffe, $f 115$ millioen van de suiker en slechts 27 millioen van de overige artikelen $(*)$. Doch hij erkent, dat men aan zijne cijfers niet al te groote waarde moet hechten, omdat van vele der artikelen de officieele statistiek ontbrak. "Zooals ik reeds opmerkte", zegt hij, , zijn deze cijfers niet als volstrekt juist te beschouwen. Alleen voor de jaren 1840-1863 (en zelfs hier nog niet eens voor alle artikelen, want voor de koffie en cochenille ontbreken zij) stonden mij de officieele statistieken ten dienste, die de regeering in 1865 heeft uitgegeven; al het overige moest berekend worden door vermenigvuldiging der aan het gouvernement geleverde hoeveelheden producten met het verschil tusschen de in- en netto verkoopsprijzen in ieder jaar. Deze wijze van berekening kan niet volkomen zuiver zijn, daar steeds een gedeelte der in het eene jaar verkregen producten in het andere jaar zal zijn verkocht; en hoewel ik getracht heb de waarheid naderbij te komen door de gemiddelde prijsverschillen in elke vijf jaren met de gezamenlijke in dat tijdsverloop geleverde hoeveelheden te vermenigvuldigen, zoo is daardoor volkomen nauwkeurigheid nog niet verkregen. Maar ik geloof dat de algemeene indruk, dien de bovenstaande tabel achterlaat, toch juist kan heeten. $(\dagger)$

zijn als Bïlagen overgelegd overzichten van de uitkomsten der verschillende kultures. De eenigste kultuur, die toen nog winst gaf, was die van de indigo; maar die winst stond niet in verhouding tot de bezwaren voor de bevolking.

(*) Hiervan zal de indigo zeker het grootste deel uitmaken.

(t) Pierson, bla. 148 sq. 
Het is dus niet te ontkennen, dat vooral de gedwongen koffiekultuur en ook de suikerkultuur zeer groote baten hebben afgeworpen. Het doel van het stessel was om te voorzien zoowel in den financieelen nood van het vaderland als in de administratie van Indië zelf. Aan den financieelen nood van het moederland heeft die groote bate een einde gemaakt. Zelfs heeft Nederland zijn uitgebreid spoorwegnet er mede gebouwd, en een aanzienlijk bedrag zijner schuld geamortiseerd, maar aan de andere zijde is het niet te ontkennen, dat die zelfde bate ook demoraliseerend heeft gewerkt. Ons geheel financiewezen leunde op de saldo's uit Indië; men verzuimde in tijds het vicieuse belastingstelsel te verbeteren; men leefde als bij den dag, van de hand in de tand. Te vergeefs hebben financieele specialiteiten bij tijds gewezen op de gevaren, die zouden ontstaan, indien die baten door onvoorziene omstandigheden ons zouden komen te ontvallen. Dat tijdstip is aangebroken. De begrooting van het dienstjaar 1877-1878 schreef achter den post van bijdrage uit Indië het woord "memorie", en het Indisch dienstjaar 1879 sluit met een nadeelig slot van 10 millioen!

En Indie? het werd stiefmoederlijk behandeld; het zag zijne eigene behoeften onbevredigd; wij zagen boven reeds hoe voor elke uitgave vooraf de onvermijdelijke noodzakelijkheid daghelder moest bewezen worden $(*)$; eerst later, toen het geweten der natie ontwaakte, deed men iets als met loome schreden tot verbetering van den toestand ginds. Het onderwijs werd verwaarloosd, land- en waterwegen en bruggen werden niet onderhouden en werden onbruikbaar - voor waterafleiding werd niets gedaan. Aan de dringende behoefte aan spoorwegen moest het initiatief eener particuliere maatschappij tegemoet komen, en toen deze door onvoorziene omstandigheden in geldgebrek verkeerde, en de hulp van den Staat inriep, werd die niet dan schoorvoetend en omdat men hier anders kon, verleend. Eerst sedert kort ligt oen lijn van staatswege en is men begonnen voor Batavia eene haven te bouwen. Kan het bevreemding wekken, dät zich in Indië eene onterredenheid openbaart? Is het wonder, dat men ginds aandringt op eene betere regeling van de fanancieele verhouding met het moederland?

Doch laat ons thans zien, wat in den laatsten tijd gedaan is, om hetgeen nog overgebleven is van het kultuurstelsel te temperen

(*) Zie boven bly. 5. 
en te verlichten. Het Vle hoofdstuk van het werk des heeren Pierson voert ten titel „Hervorming."

In de eerste plaats gaat de schr. de laatste regeling der suikerkultuur na, zooals die bij de wet van 21 Juli 1870 heeft plaats gehad. Hier echter zouden wij het ernstig betwijfelen, of die regeling in alle opzichlen als eene "hervorming" mag beschouwd worden. Naar onze overtuiging had de toenmalige regeering bij den grooten steun, die zij bij de Vertegenwoordiging ondervond, eene veel betere regeling tot stand kunnen brengen. Eigenlijk is de suikerregeling gebleven wat zij was. In één opzicht heeft de wet een zeer goed beginsel gehuldigd, nl. om voor goed te breken met het eontractenstelsel; immers na de invoering der wet kan geene nieuwe invoering van de suikerkultuur op hoog gezaig meer plaats hebben, èn daarmede wordt dus de gedwongen beschikking over de gronden, en, met betrekking tot den verplichten aanplant, ook over de werkkrachten der inlandsche bevolking, als in strijd met de eischen der rechtvaardigheid en met die van het staatsbelang opgeheven. Dit is op zich zelf een niet to miskennen stap op den goeden weg. Doch daarbij werd tevens bepaald, dat de beschikking over den grond, en dus ook de verplichte aanplant door de bevolking eerst in 1.890 een einde neemt, al worden beiden na den oogst van 1878 voor elke onderneming jaarlijks verminderd. Onder die en andere voorwaarden - wier vermelding wij hier gerust kunnen laten rusten - kunnen de bestaande contracten worden verlengd tot 1890 . Het is waar, in stede van de levering van het product in natura aan het gouvernement, wordt voortaan eene jaarlijksche cijns in geld aan de contractanten opgelegd, en zijn ook eveneens de plantloonen beter geregeld; ofschoon die al verbetering hadden ondervonden bij besluit van den Gouverneur-Generaal van 4 Mei $1866\left(^{*}\right)$, terwijl ook reeds in 1863 bepaald is, dat het snijden en vervoeren van het riet, alsmede de werkzaamheden in en bij de fabriek in vrijen arbeid moeten geschieden. Bovendien wordt bij de wet van 1870 verboden te beschikken over water dat voor de inlandsche landbouw noodig is. Doch al mogen dergelijke voorschriften een bewijs zijn van vooruitgang, en getuigen van eene mildere toepassing van liberale beginselen, de wet van 1870 laat de zaak grootendeels zooals zij was tot 1890. Daarbij komt, dat na dat tijdstip de toekomst der industrie zeer donker is.

(*) Bijbl. op het Ind. Staatsbl. 1865, nn. 1849. 
Het doel toch van eene nieuwe regeling moest zijn niet alleen in den kortst mogelijken tijd de gedwongene en kunstmatige industrie in eene vrije te herscheppen, marar ook maatregelen te beramen, die hare instandhouding en uitbreiding zou verzekeren. Daarin is zij - gelijk wij meenen - te kort geschoten.

Wij. erkennen gaarne, dat de toestand, waarin de suikerkultuar verkeerde, die een kunstmatige was omdat zij alleen door het gezag der regeering bestond, niet in eens kon worden opgeheven; dat een tijd van overgang' noodig is, omdat de billijkheid medebrengt, dat de contracten - wier bezitters in den laatsten tijd ' $t \mathrm{zwaar}$ te verantwoorden hadden èn door de onzekerheid van de toekomst hunner onderneming, èn door de inmiddels opgekomene concurrentie met de beetwortelsuiker - dat de contracten, zeggen wij, verlengd worden, omdat de fabrikanten tijd moeten hebben om zieh voor te bereiden voor den nieuwen toestand. Doch was 't daarvoor noodig een termijn te bepalen, die voor verreweg de meesten niet minder dan zestien jaren zou zijn? $\left(^{*}\right)$ Maar de kwestie van kortere of langere termijnen voor een oogenblik daargelaten waar het vooral op aankwam, dat was in allereerste plaats eene milde en ruime toepassing en uitvoering van de agrarische wet, en met name de bevordering van de conversie van het communaal in individueel grondbezit. Zonder die conversie, wat baat de geheele regeling, wanneer de tegenwoordige ondernemers na expiratie der contracten niet in staat zullen zijn de velden te huren, om daarop het riet te planten, of met de inlandsche eigenaren contracten te sluiten tot den verbouw van het riet? Zonder die conversie, hoe zal de vrije industrie zich kunnen ontwikkelen? Het contracteeren met geheele dessa's is sedert 1863 verboden $(\dagger)$, en al ware het niet verboden, het zou dáar, waar communaal grondbezit bestaat, en waar de verdeeling der gronden onder de gerechtigden jaarlijks plaats vindt, zelfs onmogelijk zijn, tenzij men zijne toevlucht neme tot knoeierijen met- en omkoopingen van dessahoofden, die niemand zal terug verlangen. Immers hier ontmoeten wij de ordonnantie van den Gouverneur-Generaal van 30 Oct. 1871 (Ind. Staatsbl. no. 163), houdende regelen volgens

(*) Van de 92 contracten, die op het tijdstip der invoering van de wet bestondeu, was één, die reeds in 1869 geëxpireerd maar met één jaar vérlengd was; één expireerdo in 1870. Van de overigen liepen 77 tusschen de jaren 1871-1877, (verreweg de meesten vervielen in 1872) en 13 tusschen 1878-1882 af.

(†) Ordon, v. d. Gouv,-Geur. 13 Nov, 1863 (Iud. Stbl. no. 152.) 
welke verhuur van gronden door inlanders aan niet-inlanders geschieden kan. Bij art. 5 van die ordonn. wordt bepaald, dat de deelgenoot in gemeentegrond het hem toegewezen aandeel in dien grond alleen verhuren mag voor het tijdvak van zijn genot, d. i. bij jaarlijksche wisseling, voor den tijd van één jaar, terwijl het beding van wederinhuur na verloop van dien tijd verboden is. De verdeeling der dessagronden heeft meestal plaats in October; de suikerkultuur heeft de velden noodig van April of Mei tot ongeveer Sept. of October van het volgende jaar, zoodat elke suikerrietaanplant juist in twee achtereenvolgende verdeelingen van den commimalen grond invalt. Men weet niet wie de gebruiker zijn zal bij eene volgende verdeeling. Doch al eens aangenomen, dat het dessabestuur den ondernemer toezegt, dat het de met riet bebouwde velden in het bezit zal laten van den actueelen gebruiker, welke waarborg heeft de ondernemer, dat indien hij met het dessahoofd ongenoegen krijgt, deze niet tegen zijne toezegging in, toch de velden bij de jaarlijksche verdeeling aan een ander toekent, en de nieuwe bezitter weigert met den ondernemer te contracteeren? $\left(^{*}\right)$ Bovendien hoe kan de ondernemer met $a l$ de deelgenooten van de communale gronden onderhandelen? hoe eenstemmigheid verkrijgen, zonder hulp en medewerking van het dessabestuur? ( $\dagger$ ) Voor de kultuur is het een vereischte, dat de

$\left(^{*}\right)$ Zie correspoudentie tusschen de heeren G. F. C. Rose en mr. J. Hulshoff Pol over deze kwestie in het I deel van den vorigen jaargangr van de Economist, blz. 418 en volg.

(†) In de boven genoemde enrrespondentie beroept zich de hr. H. Hulshoff Pol op de circulaire van den directeur vau het biunenl. bestuur dd. 8 Febs. 1875, waarbij deze hoofdambtenaar aan art. 5 van de meer genoemde ordonantie vau 30 Oct. 1871 de uitlegging gegeven heeft, "dat bij verhuur vau gronden door deelirenooten in den gemeentegrond, waar de verdeeling elk jaar geschiedt, ook de verhuur kan plaats hebben voor een langeren termijn van eén jaur, mits bimen de grenzen, gesteld in dat artikel (l.i. 5 jaren), indien slechts de verhuurder zich door overleg met de medeleelgenooten heeft verzekerd van het genot over de overeengekomene-buartermiju, en dat lus dergelijke overeenkomsten kunnen worden geregistreerd, uadat zal ziju gebleken, dat werkelijk de verhuurder het genot heeft gedurende den vastgestelden termijn." De heer Rose heeft in het Tijdschrift van Nederl. Indie (Vei 1878) daarop geantwoord, dat de onderuemer in dat geval toch de medowerking noodig zal hebben vau het dessabesture, en dat meu op die wijze weder de deur openzet voor geknoei en omkooperij. Naar ons gevocleu heeft de lheer Rose gelijk. Boveudien zal door de wijze, warop de direkteur van het biunenl. bestuur aau het bezwaar wil tegemoet komeu, de conversie van conmunaal in individueel grondbezit nog lang wurden tegreugehouden. 
ondernemer zooveel mogelijk beschikken kan over aaneengelegene gronden. Merkwaardig is 't, dat, blijkens het Koloniaal Verslag over 1878 de hoofdinspecteur der kultures de bovengenoemde bezwaren erkent. „Hij betoogde," dus leest men op bladz. 94, ${ }_{n}$ dat de suikerfabriekanten onder de bestaande bepalingen in de streken, waar communaal bezit regel is - slechts door conniventie met de dessaboofden de benoodigde gronden voor den aanplant van suikerriet in huur konde krijgen." Het door dien hoofdambtenaar aangegeven denkbeeld, om de communaal bezeten gronden alleen te doen verhuren in overleg met de gezamenlijke deelgerechtigden, is te recht afgewezen op grond, dat die maatregel aan de conversie in individueel bezit langer dan noodig zou in den weg staan. Verder blijkt wel is waar uit hetzelfde Verslag, dat een door den Landroogd ingesteld onderzoek bewezen heeft, dat het voorschrift, dat elk deelgerechtigde in de gemeene gronden zijn aandeel slechts mag verhuren over den tijd van zijn genot, in geen enkcl gewest bezwaar heeft opgeleverd, zelfs dáár niet, waar jaarlijksche verdeeling van de velden gebruikelijk is, omdat het dessabestuur den gebruiker nooit weigert hem.zoo lang als het noodig is, in het genot van zijn aandeel te laten $\left(^{*}\right)$; doch op deze wijze wordt dan toch ook de conversie in individueel grondbezit tegengehouden, en bovendien zouden wij vreezen, gelijk wij boven aanteekenden, dat daardoor knoeierij en omkoopingen niet zullen kuunen worden voorgekomen, al wordt ook door de regeering een verscherpt toezicht uitgeoefend.

Naar onze overtuiging kan alleen de toekomst der suikerindustrie verzekerd worden door de conversie van communaal in individueel bezit $(\dagger) . \mathrm{Nu}$ erkennen wij, dat die conversie, sedert de regeering haar schijnt te laten rusten, nog lang op zich zal laten wachten. Maar dan zou 't de vraag zijn, of niet wellicht als maatregel van overgang zou kunnen dienen, dat de regeering bepaalde, dat de verdeeling der gronden, waar zij jaarlijks geschiedt, oin de drie of rijf jaren plaats hebbe. In de eerste plaats zou een dergelijke maatregel als voorbereiding kunnen strekken, om eindelijk tot de conversie van communaal en individueel grondbezit te geraken, omdat de bevolking de waarde van het bezit zou

(*) De hr. Rose ontkent die medewerking: "hoogstens zon men kunnen beweren dat het geschiedt onder berustiog van de deelgerechtigden." Econom. 1878, I , 418.

(f) Men gelieve zich te herinneren wat reeds du Bus in zijn bekend rapport gezegd beeft. Zie miju artikel in de Econom. 1878, blz. 827. 
leeren inzien, en in zoo ver zou dus een dergelijke maatregel zeker in het belang zijn der conversie; ten andere zouden de fabriekanten ten minste voorloopig geholpen zijn. Te eer kunnen wij dezen maatregel aanbevelen, omdat, blijkens het Koloniaal Verslag over 1877, reeds in Rembang eenige dessa's, waar vroeger de gronden om de 2 of 3 jaren werden verdeeld, reeds daartoe zijn overgegaan, ten einde de gronden voor 5 jaren aan de suikerfabriekanten te kunnen verhuren, zonder dat 't blijkt, dat er bezwaren aan verbonden zijn $\left({ }^{*}\right)$.

Uit bovenstaande beschouwingen is het duidelijk, dat wij niet instemmen met den heer Pierson, wanneer hij gunstige verwachtingen koestert voor de toekomst der suikerindustrie. „Ik geloof dan ook niet", zegt hij, „dat de suikerkultuur op Java met ernstige gevaren wordt bedreigd, want de vrije aanplant schijnt nict duurder te zijn dan de verplichte" ( $\dagger$ ). Op dien grond behoeft men voor de toekomst der industrie geene vrees te koesteren, want zij kan nog veel uitgeven, en toch met voordeel werken. Maar de gevaren dreigen vooral uit de onzekerheid, hoe men over genoegzame gronden kan beschikken. En over dat punt zwijgt de heer Pierson.

Doch wat betreft de bewering van den geachten Schr. dat de vrije arbeid niet duurder zal zijn dan de verplichte, daarover heeft de heer Hulshoff $\mathrm{Pol}$ in den vorigen jaargang van den Economist reeds een woord gezegd (§). Vooreerst kan volgens dien Schr. over die kwestie nog niet voldoende worden geoordeeld, nomdat de tijd der concurrentie nog niet aangebroken is." Maar ten andere leert het voorbeeld der vrije tabaksteelt, dat de bevolking hier en daar $f 300$ per bouw maakt; hoe kan dan worden verwacht, dat de bevolking tegen veel geringer belooning de oneindig veel $z$ waarderen arbeid voor de suikerkultuur zal willen verrichten. Terwijl zij thans onder de werking der gouvernementsbemoeiing ongeveer $\int 150$ per bouw ontvangt, lazen wij in het Koloniaal Verslag over $187 \bar{\imath}$, dat $n$ de beste uitkomsten worden verkregen, waar de ondernemers de gronden huren en voor eigen rekening laten bewerken. Eene bouw suikerriet met zorg bewerkt en onderhouden komt hun op $f 200$ à $f 300$ te staan" (*). En

(*) B31z. 93.

(†) Pierson, blz. 173.

(\$) "De belangen eener noodlijdende industrie" E'conomist 1877 II blz. $101 \%$.

(*) Koluniaal Verslay 1877, blz. 203. 
daar, waar de suiker door de inlandsche bevolking wordt geplant, b. v. in Japara, brengt eene bouw goed geslaagd riet tot $f 400$ op $\left(^{*}\right)$. Dat laatste voorbeeld zal wel een exceptioneel geval zijn geweest. Doch wij betwijfelen of de opgave van den heer Holshoff Pol juist zijn. In het laatste Koloniaal Verslag toch worden eenige huurprijzen aangegeven in verschillende gewesten, welke huurprijzen naar gelang van de streek, den aard der gronden en de bijzondere bedingen varieeren tusschen $f 10$ en $f 60$ ( $\dagger$ ). Doch wat hiervan zij, wij herhalen, op dien grond behoeft men geene vrees te koesteren; wij zijn 't met den heer Rose eens, „dat de winsten van de industrie kleiner kunnen zijn, naarmate zij zekerder zijn, en dat men eerder geld zal steken in eene industrie, al geeft zij kleine winsten, wanneer haar bestaan verzekerd is, en men dus voor het kapitaal niet behoeft te vreezen, dan wanneer het gemis aan een gezonden grondslag en rechtszekerheid den toestand geheel preoair maakt" (\$). Dat laatste nu doet juist gevaar. voor de toekomst vreezen.

De suikerindustrie is eene van de belangrijkste op Java, niet alleen omdat de suiker een voornaam artikel van uitvoer is, maar ook wegens het anzienlijk kapitaal, dat er mede gemoeid is. Ook voor de inlandsche bevolking is zij van gewicht, omdat er veel mede verdiend kan worden, en ook wegens de vele bedrijven, die bij elke onderneming gevonden worden $\left({ }^{* *}\right)$, welke allen vervallen, zoodra de onderneming te gronde gaat. Het is dus van groot belang, dat men op middelen bedacht zij, om hare toekomst te verzekeren. $\mathrm{Zij}$ heeft eene zware concurrentie door te staan met de beetwortelsuiker-industrie. Niemand is zeker beter in staat om de treurige gevolgen nategaan van den achteruitgang en eindelijk geheele vernietiging der industrie dan de heer Pierson zelf, en niemand zal zeker met meer energie voor hare instandhouding willon ijveren, dan hij, de man van de praktijk en de wetenschap. Hij late zich voorlichten door bekwame, zelfstandige mannen, die het alytmeen brlang in het oog houden, die de industrie van nabij kennen, en in staat zijn de middelen harer instandhouding te beoordeelen.

Nog een enkel woord over den eijns. Er wordt beweerd dat de wet van 1870 aan de ondernemers een aanzienlijk voordeel heeft

(*) Kol. Versl., blz. 190.

(†) Ibid. 1878, blz. 93.

(§) Economist 1878 I 420.

$\left({ }^{*}\right)$ Bv. smederijen, potten- en steenbakkerijen, karrevoetderij, en\%. 
bezorgd. Dat is onjuist. 't Is waar, vroeger genoot de Staat ruim $5^{n}$ millioen, thans ruim 4 millioen; maar van dat $1^{5}$ millioen verschil moet men aftrekken de kosten van oprichting en onderhoud der pakhuizen ter opneming der suiker, die de fabriekanten aan het gouvernement moesten opleveren, en die nu niet meer noodig zijn (*). Welk cijfer daarvoor noodig was, kan moeilijk worden opgegeven, maar zeker zal dat. bedrag niet onaanzienlijk zijn geweest. De fabriekanten echter betalen over 't algemeen niets minder dan vroeger, en van eenig voordeel hunnerzijds, boven 't geen hun uit de regeling van 1863 toekwam, is geen sprake. Hun voordeel bestaat vooral daarin, dat zij nu zoodanige suiker kunnen maken, als zij verkiezen, terwijl zij vroeger-aan bepaalde suikernummers, althans wat de gouvernements-levering betreft, gebonden waren.

Ten slotte: is het verdedigbaar, vraagt de heer Pierson, dat de schatkist het offer van $1^{8}$ millioen heeft gebracht? Wij vereenigen ons met het antwoord, dat hij zelf geeft : „eene regeering, die een gedwongen kultuur in eene vrije wil oplossen moet vooral niet te zuinig wezen" $(\dagger)$.

In de tweede plaats vestigt de heer Pierson de aandacht op de hervorming van het Preanger-stelsel. En hier geldt ' $t$ inderdaad eene zaak, die in waarheid eene hervorming mag heeten.

Wat was de toestand der Preanger-Regentschappen? en welke wijzigingen zijn daarin aangebracht?

nOnder deze benaming (nl. van het Preanger-stelsel) wordt in algemeenen zin verstaan dat samenstel van bestuursinrichtingen, volgens hetwelk in de Preanger-Regentschappen, in afwijking van de elders op Java toegepaste regeerings-beginselen, door het gouvernement geene landrente, noch andere belastingen van de bevolking gevorderd, en aan de inlandsche regenten geen tractement toegekend werd, maar aan deze de bevoegdheid is gelaten, om van de bevolking belastingen te heffen, onder gehoudenis om in de bezoldiging der inlandsche hoofden te voorzien, terwijl de bevolking verplicht werd tot de teelt van koffie en tot de levering van dat product aan het gouvernement tegen minderen prijs, dan in de andere gewesten betaald werd" (\$).

(*) Piurson, blz. 170

(†) Ibid. bla 171 .

(\$) Zie kul. Versl. over 1870 blz. 44. 
Te recht zegt de heer Pierson: „het Preanger-stelsel was een legaat der Oost-Indische Compagnie. Toen haar regeerings-stelsel in de meeste andere residentiën van Java, als strijdig met de belangen van het gouvernement en bevolking, werd verlaten, is het in de Preanger-Regentschappen om financieele redenen behouden". (*).

Eerst bij het Regeerings-Regl. van 1830 achtte men het noodig uitdrukkelijk te verklaren, dat in de Preanger-Regentschappen de oude toestand bestendigd zou blijven. Terwijl voor al de gewesten op Java, de gronden, welke nog de eigendom van den Lande waren, bij voortduring dessa'swijze aan de inlandsche bevolking verhuurd werden door middel van overeenkomsten met de hoofden en oudsten, waarvoor de bevolking dan de landrente zoude betalen, en dus het eigendomsrecht op al de gronden - voor zooverre zij niet door de Oost-Ind. Compagnie aan particulieren verkocht waren - gehandhaafd werd, verklaarde men dat beginsel niet toepasselijk op de Preanger-Regentschappen en 、 bepaalde men dat "aldaar de thans bestaande inrichtingen ongeschonden zullen worden bewaard", met dien verstande, dat ${ }^{2}$ de an den Lande verschuldigde grondhuur bij voortduring zal worden voldaan door middel eener verplichte teelt en levering van koffie, en niet anders", met deze bijvoeging echter: \#zoolang daaromtrent niets anders door den Koning zal zijn bevolen" $(\dagger)$. Men schijnt dus toen reeds aan de mogelijkheid, misschien ook aan de wenschelijkheid gedacht te hebben, om to zijner tijd in dat stelsel verandering te brengen. Hetzelfde voorschrift vindt men in art. 64 van het Regeer. Reglem. van 1836. In het tegenwoordige Regeer. Regl. mist men een dergelijk artikel, en al was men reeds in 1830 en 1836 rrij om de noodige wijziging te brengen in het genoemde stelsel, thans was men het nog meer.

Het Preanger-stelsel kwam dus hierop neder: de bevolking betaalde hare regenten, hoofden en priesters. De regenten genoten groote voordeelen o. a. die van Bandong $f 99000$, die van Soemadang $f 47000$, die van Tjandjor $f 30.000$, die van Lembang $f 19000$ enz. De belasting die de regenten hieven heette tjoeké; zij werd geind van het rijstgewras en bedrocg ${ }_{1}^{1}$, , en in natura opgebracht, terwijl de bevolking de rijst zelve moest brengen naar de pakhuizen van den regent. Hieruit werden ook de mindere hoofden betaald. Verder hieven de regenten een zeker recht op de passers en

(*) Pierson, blz. 174.

(†) Zie art, 76 van de public, vąn $19 \mathrm{~J}_{\text {aqu, }} 1830$. 
warongs, op de visscherijen en op het slachten van vee, op feesten bij huwelijken, geboorten en besnijdenis, de porpoend joetan geheeten. Bovendien konden de regenten vorderen het leveren der schoonste paarden tegen verminderden prijs. Eindelijk maakten zij een overvloedig gebruik van heerendiensten $\left(^{*}\right)$. De bevolking moesten de velden der hoofden bewerken, gras snịjden voor hunne paarden, materialen leveren voor hunne gebouwen, enz. Deze

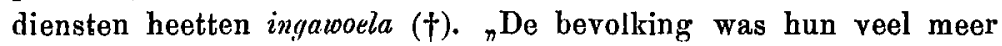
onderworpen dan op andere plaatsen, veel meer zelfs dan het geval zou zijn geweest, indien er geen Nederlandsch opperbestuur had bestaan. De anwezigheid van dat bestuur, de eerbied, dien de bevolking daarvoor koesterde, de zekerheid, die zij bezat, dat het de regenten zou te hulp komen, indien zij het waagde, om zich tegen hun bevelen te verzetten, dit alles droeg daartoe bij. Van daar dat de levering van huishoudelijke benoodigdheden, zooals rijst, kippen, groenten en brandhout, die de bevolking bij plechtige gelegenheden - huwelijken, geboorten en besnijdenissen van de bevolking plegen te verkrijgen in de Preangerlanden veel regelmatiger en in veel grooter hoeveelheden geschiedde, dan in andere gedeelten van Java. Elders zijn de leveringen geschenken; de bevolking is vrij om ze al of niet te geven; hier werden zij geëischt en waagde niemand om ze achterwege te houden. Van daar dat ook de bevolking in de Preanger veel minder zeker was van het ongestoord bezit harer roerende goederen, zoo als sieraden, buffels, paarden. Werd het beste daarvan haar afgenomen, zij had geen moed om zich daartegen te verzetten. Van daar eindelijk dat de diensten aan de hoofden hier veel drukkender waren dan elders.... Om niet bloot te staan aan de knevelarijen van iederen machthebbende, hadden vele inlanders de gewoonte aangenomen van zich bij zoogenaamde vrijwillige overeenkomsten in dienst te stellen van bepaalde hoofden of invloedrijke grooten" (\$).

Ook de priesters hieven hunne inkomsten. Wat elders gegeven werd uit eene soort van piëteit, werd hier ingevorderd; ook zij hieven eene belasting, de dzakat, zijnde ook $\frac{1}{1}$ van de rijst; verder I' $^{\prime}$ van de beesten, van goud en zilver, benevens $T^{\prime} \pi$ van boedelscheidingen; bovendien eischten zij een soort van hoofdgeld, de pilzal tegen het einde der vasten, terwijl zij bovendien nog

$\left(^{*}\right)$ Zie Rede van den Hr. Sloet vă de Beele in de 2de Kamer. Handelingen zitting 1869/1870 blz. 132.

(t) Pierson, blz. 176.

(j) Ibid., blz. 175 sq. 
aanspraak maakten op giften van levensbehoeften in zekere maanden des jaars. „Wij mogen aannemen, dat de bevolking ruim $f 350,000$ 's jaars aan hare geestelijkheid opbracht" $\left({ }^{*}\right)$.

En ten slotte, voor de verplichte levering van koffie kreeg de bevolking $f 6,50$ per pikol, toen reeds elders de prijs tot $f 13$ per pikol was opgevoerd.

Gaan wij thans kortelijks na welke wijzigingen in dat stelsel zijn gebracht. Men vindt ze in het Ind. Staatsbl, van 1870 onder nrs. $121-124$; het voornaamste is dat onder nr. $122(\dagger)$. Daarbij is ,het aan de regenten in de Preanger-Regentschappen tot dus ver gelaten recht van de belastingheffing in geld, in producten en in arbeid, zoomede de algemeene dienstbaarheid der inlandsche bevolking (inyaworla) aan de hoofden en aanzienlijken des lands of andere personen afgeschaft." Verder werden van wege den Staat de drie navolgende belastingen direkt geheven, nl. op de rijstkultuur, op het bedrijf, en op het slachten van buffels en rundvee. Bij ordonnantie van 25 Sept. 1870 (Stbl. nr. 124) werden aan de regenten hun toenmalig tractement prrsoonlijk vastgesteld, als volgt: aan de regenten van Tjandjor, Bandong en Soemadang ieder $f 44,000$, an de regenten van Limbangan en Soekapoera ieder $f 20,000$, terwijl ieder hunner kultuurprocenten werden toegekend tot een maximum van $f 30,000$ voor die van Tjandjor en Soemadang ieder, van $f 83,000$ voor dien van Bandong, van $\int 10,000$ voor dien van Limbangan, en $\int 6,000$ voor dien van Soekapoera. Ten behoeve van heerendiensten waarop de regenten en anderen hoofden aanspraak hadden, werden de besluiten vau 28 Sept. 1867 (Ind. St. no. 122, 123 en 124) toepasselijk verklaard. Ook werd weldra de koffieprijs gelijkgesteld aan dien der overige gewesten. Voor de priesters werd van staatswege niet gezorgd; de bevolking was even als elders vrij of zij al dan nict in humue behoeften wilde voorzien.

Nog eene herinnering uit het Parlement dat over de opheffing van het Preangerstelsel moest beslissen. De beraadslagingen waren nog niet aangevangen in de Eerste Kamer, toen reeds het gerucht liep, dat de besluiten tot wijziging van het Preanger-stelsol in Indië waren afgekondigd, en men dus stond voor cen fait accoumpli. De Minister van Koloniën, de heer de Waal, in de Tweede Kamer

$\left(^{*}\right)$ Pierson, blz. 177. Zie al de op het Preangerstelsel betrekkelijke stukken in de Bijlagen tot de Handelingen der St. Gener. 1870/71; blz. 1223 en volgende,

$(\dagger)$ Zic verder Ind. Staatsbl, 1871 ar. 46 en volgende. 
daarover geinterpelleerd door den heer Insinger, ontkende de afkondiging en verklaarde dat er geen Koninklijk Besluit bestond. In zoo ver was zijne mededeeling juist, dat het besluiten waren van den Gouverneur-Generaal; maar was 't goed van hem gehandeld, dat hij zich op dat verschil beriep? Genoeg zij 't dat wij hier anteekenen, dat ofschoon aanvankelijk de invoering op den 1 Jan. 1871 bepaald werd, de regeering, tengevolge van hare minder juiste mededeeling aan de Kamers verplicht is geworden die uitvoering te schorsen $(*)$, on haar eerst den 1 Juli 1871 te doen plaats hebben ( $\dagger$ ).

En de bevolking? terecht zegt de heer Pierson: , het is verblijdend om jaarlijks in de Kolon. Verslagen te lezen ( $\S$ ), hoe snel deze residentie vooruitgaat en hoe uitnemend de genomene maatregelen werken. De gunstige berichten zijn sedert dien tijd bevestigd, en de hervorming van het Preangerstelsel mag dus worden aangemerkt als eon der nuttigste en best geslaagde maatregelen, die in de laatste jaren ter verbetering van maatschappelijke toestanden op Java zijn genomen. Al de sombere voorstellingen harer bestrijders zijn gelogenstraft en de uitkomsten zoo gunstig geweest als men redelijkerwijs kon verwachten. Op nieuw is gebleken, dat de gehechtheid eener Aziatische bevolking aan hare aloude gebruiken haar geenzins belet, om veranderingen, die bevorderlijk zijn aan hare welvaart, met ingenomenheid te begroeten. Zal deze waarheid, na de op Java en in Britsch-Indië zoo dikwijls verkregene ondervinding, nu eindelijk algemeen erkend worden" $(* *)$.

Wij komen thans aan de hand des heeren Pierson tot de koffiekultuur.

Het is niet te ontkennen, dat de koffie eene in vele opzichten nog belangrijker kultuur is dan de suiker, eensdeels omdat zij eene volkskultuur worden kan, zeer ten bate van de bevolking, anderdeels omdat zij als monopolie van den Staat eene groote bron is van inkomsten voor den Staat. Een meer of minder gunstige oogst, de daling of rijzing van de koffieprijzen op de Nederlandsche markt oefenen eenen geduchten invloed op het budget

(*) Zie Ind. Staatsul. $1870 \mathrm{nr} .199$ en 200.

(t) Zie Iud. Stbl. 1871 nr 45.

(\$) Het laatst maakt het Koloniaal Verslag over 1875 melding van de Preauger,

$\left.{ }^{* *}\right)$ Pierson, blä. 180, volg. 
van Nederland en Indië uit. Eéne cent verschil per pond is een verschil van een millioen op het totaal. De groote ingenomenheid, die men hier te lande koesterde met de enorme winsten, welke voornamelijk uit dit monopolie van den Staat voortsproten - de heer Pierson heeft ergens gesproken van gelddorst - heeft gemaakt, dat men op allerlei wijze, zelfs met achteruitstelling van de belangen der bevolking, telkens den aanleg van meerdere koffietuinen bevorderde, en zich niet ontzag daarvoor zelfs de beste gronden, welke aan de bevolking behoorden, zich toeteeigenen. Zoolang men Indië beschouwde als eene pachthoeve, waarvan het meest mogelijke voordeel moest getrokken worden, scheen niets natuurlijker, dan dat men juist zulke gronden benuttigde, die de meeste voordeelen konden opbrengen; maar in zijnen ijver ging men dikwijls te ver; er werden tuinen aangelegd op berghellingen, zonder voorzorgen, dat de humus door de zware regens er niet van afwaterde - hellingen, waarop men zich niet dan met gevaar kon bewegen. Er werden zelfs maar al te dikwịls tuinen aangelegd op gronden, die later bleken zeer ongeschikt te zijn, en die men spoedig daarna moest verlaten. Intusschen had de bevolking al den arbeid om niet gedaan $\left({ }^{*}\right)$. Er zijn voorbeelden, dat er aanplantingen hebben plaats gehad, wier aanwezen bij de Nederlandsche ambtenaren, met het toezicht belast, niet vermoed werden, maar die desniettemin keurig in orde waren gehouden. Terwijl de particulier aan de verfraaing van zijne tuinen niets te koste legt, geleek de gouvernements-aanleg volkomen aan ware tuinen, in den letterlijken zin des woords, met geregelden paden en keurige omheiningen - alles tot noodeloos groote lasten der bevolking. Reeds boven merkten wij op, dat zij den grond moet bearbeiden voor den aanleg, de stekken moet planten in voldoende hoeveelheid, en den tuin onderhouden gedurende al den tijd, dat de heester geene vrucht draagt, zonder voor al dien arbeid eenige vergoeding te bekomen. Eerst wanneer de boom vruchten afwerpt - en daarvoor heeft hij noodig een groeitijd van ongeveer 5 à 6 jaar - begint de betaling per pikol. En al is die prijs in den laatsten tijd verhoogd, hij blijft zeer gering in vergelijking tot den arbeid, die vóór dien tijd gedurende eenige jaren moet worden verricht. Daarbij komt, dat de prijs voor koffe van mindere kwaliteit ook lager is. Dit is op zich zelf juist; doch wie beoordeelt de kwaliteit? Niemand anders dan de

(*) Dit gebeurt helaas! nog te dikwijls. Zie 0, a. Kol. Versl. 1878, blz. 181. 
pakhuismeester, bij wien de bevolking de koffie moet inleveren, zonder dat van zijne beslissing ten deze eenig hooger beroep mogelijk is.

Verder moet de bevolking de door haar geplukte en bereidde koffie voor eigene rekening naar de gouvernements-pakhuizen brengen, die soms een dag reizens òf van de tuin òf van de dessa gelegen zijn. Daar moet de planter zijne beurt afwachten om afteleveren, en al dien tusschentijd zelf in zijn levensonderhoud voorzien.

Gelijk bekend is, werd, tengevolge eener aanschrijving van den Minister van Kolonien van deu 9 Sept. 1863, bij besluit van den Gouverneur-Generaal van 31 Dec. van hetzelfde jaar eene enquête bevolen betreffende de koffiecultuur op Java. Het verslag van dat onderzoek werd bij de Indische begrooting voor 1871 ingediend bij de Tweede Kamer; het duurde echter verscheidene jaren voor en al eer het geheele, omvangrijke dossier was afgedrukt, zoodat de commissie uit de Twoede Kamer, in wier handen het gesteld werd eerst in 1874 haar rapport kon uitbrengen.

Het zou ons te verleiden, indien wij de mededeelingen van het enquêteverslag hier gingen behandelen; zelfs het uitvoerig rapport der commissie blijve onbesproken. Alleen teekenen wij hior een en ander aan uit de conclusie van de meerderheid dier commissie (*), omdat daaruit de indruk wordt teruggeven, die van de lezing der enquête-stukken bij haar was achtergebleven.

Vooreerst bleek haar uit de resultaten der enquête, dat de koffiekultuur gedurende bijna 40 jaren nagenoeg stationair is gebleven, niettegenstaande het verbruik toegenomen, en de marktwaarde gestegen was, en niettegenstaande jaarlijks uitgestrekte bijplantingen hadden plaats gehad. Als eene voorname reden van dit ongunstig en zelfs onnatuurlijk feit beschouwde de meerderheid der commissie de omstandigheid, "dat onder het gouvernementskoffiestelsel de belangen der arbeidende bevolking over het algemeen niet zijn betrokken bij de vruchten van den arbeid." Verder droeg tot de minder gunstige resultaten bij, dat de leiding der kultuur was opgedragen an ambtenaren, die met enkele uitzonderingen, niet genoeg op de hoogte zijn, en somtijds onoordeelkundig met de aanwijzing van gronden, en de behandeling der boomen te werk gingen. Oolk was de belooning van den planter niet geërenredigd aan de inspanning en den arbeid, en niet in

(*) De IIr. 's Jaçob mankte alleen het lid der minderheid uit. 
verhouding met den prijs, die te verkrijgen is bij particuliere ondernemingen. Vooral is de overweging over den prijs, dien het gouvernement aan de bevolking geeft, zeer merkwaardig. „Die prijs is over geheel Java dezelfde..., deze schijnbaar gelijke belooning is inderdaad de meest ongelijkmatige. Vooreerst toch vordert de productie van zekere hoeveelheid koffie in het eene district veel $z$ waarder arbeid dan dezelfde hoeveelheid in een ander district. Ten tweede is het transport naar de pakhuizen op de eene plaats gemakkelijker dan op de andere, daargelaten dat het verzamelde product daar, waar goede en veilige transportmiddelen naar de afscheepsplaats bestaan, hoogere waarde zoude moeten bedingen, dan waar de wegen in minder gunstigen staat verkeeren. Het gevolg nu is dat in enkele streken de belooning wel voldoende schijnt om den inlander, ook zonder rechtstreekschen dwang, tot planten te nopen, maar toch in het algemeen het voordeel voor de planters uiterst gering is of eigenlijk in het geheel niet bestaat. Daarvan is eene gewichtige aanwijzing te vinden in de omstandigheid, dat de bevolking de boomen hier en daar beschadigt, doorgaans weinig zorg aan de pluk besteedt, en vooral dat eene overgroote hoeveolheid koffic wordt weggemaakt, ten einde die niet bij de pakhuizen in te leveren."

De onbetwistbare juistheid dezer overwegingen vond echter geen weerklank bij de Tweede Kamer; de conclusie der meerderheid werd den 19 Februari 1875 met 42 tegen 25 stemmen verworpen $\left({ }^{*}\right)$. Zij deed dit, omdat zij vreesde door te veel te tornen aan de koffiekultuur, het evenwicht in de financiën zoude worden verbroken, waardoor aan de groote eischen van den staatsdienst zoo hicr als ginds niet tegemoet zou kunnen gekomen worden ( $\dagger$ ).

Kort na de indiening van het verslag der enquête verscheen in Indië een besluit van den Gouverneur-Generaal van 29 Januari 1872 (§), waarbij in verband met de hervorming van het Preangerstelsel, ook eene nieuwe regeling van de koffiekultuur in de

(*) Hand. der 2e Kámer, zitting 1874/1875, blz. 795-810.

$(t)$ In het Kol. Versl. van 1874 wurlt ol blz. 185 gezegd: "dat het koliemonopolie - de verpligte levering der door de iulandsche bevolking geteelde koffie aan het gouvernement - voor 's hands moct blijven gehindhaafd, omdat het gouvernement de inkonsten, welke het aan dat monopolie ontleent, niet zon kunnen prijjsgeven zonder het financieel evenwicht in de Indische Stanthuishonding te verbreken, en zich te berooven vau de middelen, die het behoeft oun aan Lndië al datgene te geven, wat voor de ontwikkeling van laud en volk oumisbaar is,"

(\$) Zie Bijbl. op lot Ind, Staatsbl, decl XIII, ur 2738, 
Preanger-Regentschappen werd vastgesteld. Al wordt door deze regeling niet aan al de bezwaren, welke door de commissie in haar bovenvermeld verslag zijn ontwikkeld, tegemoet gekomen, toch zijn wij 't met den heer Pierson eens, dat zij in hooge mate de andacht verdient $\left({ }^{*}\right)$, niet alleen omdat zij weldra op andere gewesten van Java zal toegepast geworden, maar ook omdat daaruit duidelijk is op to maken, dat de regeering, al meent zij om financieele reden de koffiekultuur, zelfs met gedwongen arbeid en verplichte levering te moeten handhaven, tevens overtuigd is van de noodzakelijkheid om den druk voor de bevolking zooveel mogelijk te verminderen $(\dagger)$.

Bij dat besluit nu zijn eenige beginselen vastgesteld, die hoofdzakelijk hierop nederkomen: Vooreerst wordt het stelsel van aanplant in groote geregelde tuinen op verre afstanden der dessa's verlaten, om waar mogelijk is, plaats te maken voor eene meer intensieve kultuur bij den anleg van kleinere tuinen in den omtrek der dessa's en kampongs (§). Ten tweede wordt ${ }_{n}$ het oproepen in heerediensten van de bevolking, districts-, troeps-, dessa's- of poendoeks-(gehuchts)wijze, voor de bewerking van den grond, den aanplant van koffie of het onderhoud der tuinen, nildrukkelijk verbode'n." Ten derde, mag zonder uitdrukkelijke toestemming van den Gouverneur-Generaal geene koffie op hoog gezag op verderen afstand worden geplant dan 12 palen van de dessa's. In de vierde plaats moeten voor den aanleg van tuinen in de allereerste plaats in aanmerking komen de woeste gronden, die om en bij de dessa's gelegen zijn, zoodat nu geene gronden meer kunnen worden gebruikt, die voor eigen gebruik, ontgonnen, of als gemeene weiden, of uit eenige andere hoofde tot de dorpen behooren; alleen in de uiterste noodzakelijkheid kan hiervan afgeweken worden, en dan nog tegen schadeloosstelling $(* *)$. Ten vijfde is, waar woeste gronden in de naaste omgeving ont-

(*) Pierson, blz. 181.

(†) In de overwegingen van eeu later beslnit van den G.G., nl, van 30 Januari 1876 wordt gezegd "dat het hoofddoel der Preanger-regeling is, om door meer intensieve teelt met geleidelijke vermindering van bezwaren en van dwang de gouvernement-koffiekultunr meer en meer in een volksbedrijf te herscheppen." (Bijbl. tot het Ind. Staatsbl. d. XIV b]z. 98 en volgr.)

(\$) Er waren in de Preanger tuinen op afstanden, die van 15 tot 44 palen varieerden. Deze afstanden wareu een der grootste bezwaren.. Kolon. Versl. 1872, blz. 152.

(**) Zic Besl, van 30 Januari 1876 in Bijbl, tot het Ind. Stbl. XIV blz. 99. 
breken, de bevolking nog niet verplicht om op verderen afstand dan 12 palen koffie te planten, indien zij zich verbindt, om op eigen of gehuurden of wel individueel bezeten grond, in de nabijheid der dessa's, het aantal koffieboomen en tuinen te onderhouden. Ten zesde wordt het aan de bevolking vergund om de volgens het oude stelsel op verren afstand aangelegde tuinen te verlaten, mits $z i j$ daarvoor andere tuinen aanleggen op woeste of eigene gronden, waardoor het gouvernement in de gelegenheid is die aldus verlatene tuinen in te deelen bij de dessa's, die meer in de nabijheid liggen. Eindelijk wordt in de koffieregeling een nieuw element opgenomen, door nl. aan inlandsche particulieren het gebruiksrecht op de afgeschrevene of op bovengenoemde wijze door de bevolking verlatene tuinen uit te oefenen, en tevens hun de gelegenheid te geven op woeste voor de gouvernements-koffiekulkultuur gereserveerde gronden tuinen aan te leggen, met bepaling dat, wanneer de inlandsche ondernemers na rerloop van vijf jaren al hunne verplichtingen getrouw nakomen, zij beschouwd zullen worden als erfelijk individueele bezitters er van $\left({ }^{*}\right)$, doch onder voortdurende verplichting van koffie te planten en het product aan het gouvernement te leveren.

Al getuigt de regeling van 1872 van vooruitgang, toch zal zij in de uitroering tot onbillijkheden moeten leiden, omdat zij dwangkultuur tot object heeft. Zoo lezen wij o. a. in het besluit van den Gouverneur-Generaal van 29 Januari 1872 betrekkelijk de regeling zelve, dat de om en bij de dessa's gelegene woeste gronden moeten worden gereserveerd voor de koffie-kultuur, en niet dan met nitdrukkelijke toestemming van den resident bij gebleken werkelijke behoefte door de bevolking voor eigene levensbehoefte mogen worden gebruikt $(\dagger)$. Zoo zegt eene nota, houdende voorschriften betreffende de koffiekultuur in de Preanger, hieronder in de noot vermeld, o. a. dat de kultuurdienst gevorderd wordt voor de dessa, waar de kultuurdienstplichtige woont, onverschillig waar de gronden liggen, die hem kultuurdienstplichtig maakt, al woont hij ook in eene dessa, die tot nu toe niet bịj de koffiekultuur was ingedeeld (\$). Zoo zijn in de voorschriften meerdere punten,

$\left(^{*}\right)$ Zie behalve het besluit van $29 \mathrm{Jan}$. 1872, ook besluit van 31 Mei 1873 , alswede de nota, houdende voorschiften betreffende de koffiekultuux in de Preanger Regentschappen te visden in Bijbl. tot het Ind. Stbl. deel XIII, blz. 200 volg.

(t) Bijbl, tot het Ind. Stbl. deel XIII Nr 2738.

(f) Bijbl, tot bet Ind. Stbl. d. XIII blz. 200 volg. 
die niet strooken met den milden geest, welke in de regeling zelve heerscht en die van de bureancratische richting der hoofdambtenaren getuigen. Wenschelijk ware 't dus, dat het opperbestuur in het moederland de Indische regeering daarop opmerkzaam maakte.

De gelegenheid, die hierbij gegeven wordt aan de inlandsche industrie om zich te ontwikkelen verdient wel eenige belangstelling. Het Koloniaal Verslag van 1873 zegt er van, dat hieruit een drieledig voordeel voortvloeit, namelijk vermindering van druk voor een aantal planters, uitzicht op grooter productie, en opening eener nieuwe bron van industrie voor den inlander $(*)$. Hierbij zou men een vierde voordeel kunnen voegen, $\mathrm{nl}$. aanmoediging tot vrijen arbeid, omdat het onderhoud dezer merrika tuinen - zoo worden de door den inlandschen ondernemer bestuurde tuinen genoemd in vrijwilligen arbeid geschiedt; terwijl de betere zorg die men verwachten kan aan pluk en bearbeiding te zullen worden besteed, niet minder van belang is. Eindelijk houde men in het oog, dat, ingeval de maatregel gelukt, ook afgeschreven tuinen, die anders grootendeels aan zich zelven overgelaten, aan het gouvernement niets meer opleveren, nu weder productief gemaakt kunnen worden. Intusschen schijnen de gunstige resultaten, die van dezen maatregel verwacht werden, niet verwezenlijkt te zijn. Uit het Koloniaal Verslag van 1877 blijkt wel, dat het aantal merdika tuinen geklommen was tot 845 , maar dat de berichten omtrent de opbrengst niet gunstig luiden; het voordeel der exploitatie is over 't algemeen niet geëvenredigd aan de daaraan bestede onkosten $(\dagger)$. Als reden wordt voornamelijk opgegeven dat daarin een vrij aanzienlijk kapitaal moet gestoken worden (§). Wij meenen te mogen gissen, dat de oorzaak moet gezocht worden in den lagen koffieprijs, dien de inlandsche pachter van het gouvernement ontvangt, en welke prijs niet in verhouding staat tot de vrij hooge arbeidsloonen die hij moet besteden. Wij vreezen dan ook, dat de maatregel in de andere residentiën daarnm te minder zal slagen, omdat daar de arbeidsloonen nog hooger zijn dan in de Preanger.

"Zal de regeering het hierbij moeten laten? - vraagt de heer Pierson - Is alles wat wij van haar op het gebied der koffiekultuur mogen verwachten, gedaan, wanneer het Preanger-stelse

(*) Blz. 206.

(†) Blz. 190. Zie ook kol. Versi. 18'78, bl\%. 182, dat evenmin bemoedigend et over spreekt.

(\$) Kolon. Versl. 1876, แz. 177. 
in die gewesten van Java, waar zij eene verbetering kan scheppen, is ingevoerd? Het antwoord op deze vraag hangt af van het stelsel, dat in het algemeen hij het bestuur onzer kolonien, voortaan moet worden - in praktijk gebracht." - „Is", vraagt hij verder, ${ }_{n}$ het verkrijgen van direkte voordeelen, van een batig slot nog altijd doel? Zoo ja, waarom de heerendiensten dan beperkt, het Preanger-stelsel afgeschaft, spoorwegen bekostigd en eene wet uitgevaardigd, die aan de gouvernement-suikerkultuur binnen weinige jaren een einde zal maken? Waarom is dan bij herhaling besloten tot verhooging van den koffieprijs, en dien prijs niet gelaten op $f 9$, hetgeen ons eene groote bate zou geven van $f 4$ à 5 millioen 's jaars? Zoo neen, hebben wij Engelands koloniale politiek tot voorbeeld gekozen, is die ontwikkeling van Java's productieve krachten ons doel, en zoeken wij geen batige sloten, maar indirekte voordeelen? Waarom dan den ingeslagen weg zoo aarselend, zoo schoorvoetend betreden en zooveel ongedaan gelaten, wat ter bereiking van ons doel volstrekt noodig is? Van de keuze, die geschieden zal, hangt het af, welke maatregelen wij nog te verwachten hebben ten aanzien der gouvernements-koffiekultuur" $\left.{ }^{*}\right)$.

$\mathrm{W}_{\mathrm{ij}}$ behoeven het niet te zeggen, dat wij ons ansluiten bij hen, die meer het oog gevestigd houden op de indirecte voordeelen, die het gevolg zijn van het bezit van onze Overzeesche Bezittingen. Indië kan aan het Nederlandsche kapitaal, aan westersche energie en kennis een ruim veld van werkzaamheid aanbieden; en daarmede moet gepaard gaan de bevordering van de materieele en intellectueele ontwikkeling der inlandsche bevolking. "Eene natie wordt veel meer bevoordeeld door gestadige uitbreiding van haar bedrijfsmiddelen dan door batige sloten. Indien wij onze kolonien op soortgelijke wijze bestuurden als voor dertig jaar, zouden wij ons aan groote gevaren blootstellen" $(\dagger)$.

Met den heer Pierson zijn wij van meening, dat al getuigt de nieuwe regeling van de koffiekultuur van eenen meer milden geest, zij toch niet die uitbreiding van de kultuur zal bevorderen, die op Java mogelijk is; en wie zich voorstelt dat de vermeerdering van productie eenigzins te vergelijken zal zijn met die van Ceylon b. v. zal zich teleurgesteld gevoelen (§). Bovendien heeft de nieuwe regeling deze keerzijde, dat al weder woeste gronden

(*) Piersou, blz. 184.

(†) Ibid., blz. 189, 191.

(\$) Ibid., blz. 186. 
om en bij de dessa's niet aan de particuliere industrie kunnen worden uitgegeren, en juist die gronden zijn daarom het meeste waard, omdat men daar ook werkvolk kan bekomen. Doch er is meer; bij elke aanvrage om woeste gronden in erfpacht te verkrijgen, wordt met de belangen van de gouvernements-koffiekultuur te veel rekening gehouden; er worden geene gronden uitgegeven waarvan men kan nagaan, dat zij vellicht in de eerste tien jaren voor die kultuur benoodigd zullen zijn $\left({ }^{*}\right)$. Verder, omdat het gouvernement blijft wat het tot dusver is geweest, cultivateur en koopman, moet het bedacht zijn om ook rondom zijne tuinen rayons te trekken, ten einde het onttrekken van koffie uit zijne aanplantingen te beletten. Zoo wordt een dubbel rayon, nl. om de dessa en om de gouvernementstuinen, aan de particuliere industrie onthouden, terwijl eindelijk ook die gronden, welke later voor gouvernements-aanplantingen wellicht noodig zijn, voor de particuliere industrie gesloten zijn.

De bedoeling van de regeling van 1872 is, om de koffie tot eene volkskultuur te maken, zij 't dan ook met verplichte levering aan het gouvernement van het product; doch ook dit zal niet die uitkomst hebben, die men veronderstelt. Vooreerst verzet zich de prijs daartegen. Die prijs is thans $f 14$. „Laten wij aannemen," zegt de heer Pierson, „dat $f 35$ per pikol de gemiddelde marktwaarde der koffe op Java is; de bestaande regeling komt dan hierop neder, dat de inlandsche koffetterll ann eene belasting is onderworpen bedragende zestig percent van het bruto product. Wat kan er terechtkomen van de uitbreiding eener kultuur die zoo zwaar belast is?" $(\dagger)$ En elders merkt hij terecht op: "wanneer de erfpacht-ondernemingen op woeste gronden zich vermenigvuldigen, zal dan bij de inlanders de vraag niet rijzen: waarom mag de Europeaan zijn koffie tot den marktprijs - $f$ 30, $f 40$ of $f 50$ - verkoopen, terwijl wij ons product voor $f 14$ aan de pakhuizen moeten afleiden (\$)? Inderdaad de heer Pierson heeft volkomen gelijk, wanneer hij zegt: „men kan de dwangkultuur niet met kracht toepassen, en tegelijk den vrijen arbeid bevorderen $(* *)$.

Doch in de tweede plaats, indien men de vrije volkskultuur wil

(*) Kol, verslag 1875, blz. 181.

(†) Pierson, blz. 185 .

(g) Ibid., blz. 187.

(**) Ibid., b]z, 104. 
bevorderen, dan zal toch wel een voornaam vereischte zijn, dat de bevolking al dan niet daartoe vrijheid heeft. Is dat waar, hoe moet men 't dan opvatten, dat dorpshoofden, in wier dessa's de vrijwillige koffieteelt naar de meening der plaatselijke ambtenaren niet genoeg toenam, ${ }^{\text {met }}$ arrest gestraft werden? $\left(^{*}\right)$ Is dat het middel om de ontwikkeling der vrijwillige volkskultuur te bevorderen? Is 't vreemd dat in de residentie Passaroean de volkskultuur, die er bestond, zoodat dat gewest van de toepassing der regeling van 1872 kon uitgesloten blijven, te niet is gegaan, en dat het gouvernement er thans wel over denkt, om ook dáar die regeling in te voeren? $(\dagger)$

Nog een punt uit de enquête, waarvan wij boven melding maakten, moeten wij aanstippen. Bij die gelegenheid werden o. a. de navolgende drie vragen ter onderzoek en beantwoording voorgelegd:

1. „Zou een verhuur van gouvernements-koffetuinen aan particulieren tegen betaling van huurschat in geld of in natura aan te raden zijn?

2. „Gesteld, het gouvernement kon er toe besluiten het standpunt van verhuring der koffietuinen aantenemen, wat zou dan de voorkeur verdienen, verhuring aan groote maatschappijen dan wel verhuring in kleine perceelen, waarbij als het ware het oog

${ }^{*}{ }^{*}$ Zie circulaire van den directeur v. h. binnenl. bestuur van $1 \mathrm{Jumi} 1874$, te viuden in Bijbl. t. h. Ind. Stbl, deel XIlI, No. 2738.

(j) Lie Kol. Versl. 1878, blz. 181. Dáár wordt iets vermeld, dat niet duidelijk is. Wij lezen er o. a.: "Weu ander gevoly van het in Passaroean in zwang gekomen stelsel, om zich vau bestunrswege weinig of niet met de kemze der gronden voor de kothekultur of met het opleggen vau bijplantingen in te laten, bestond hierin, dat van lieverlede de meening was ontstaan, dat de bevolking, behoudens de verplichte levering van haar koffieproduct, overigeus met hare vrijzillig angelegde kuttieplantsoenen kon doen wat zij verkoos, dus ook, wauneer het haur goeddacht, de boomen kou prijs geven, en de gronden bestemmen voor de teelt van andere gewassen." Het kwam ons voor, dat die meening niet oujuist was, te meer omdat de gehoudenis van verplichte levering erkeud was. Het blijkt echter dat wij dwaalden, en dat het gouvernemeut ex anders over dacht: "de Indische regering heeft hieriu aanleiding gevonden, om te verklareu, dat het recht van het gouvernement op de plantsoenen viet mocht worden in twijfel getrokken, waar vrijwillige kultuur in plaats van gedwongeue kultuur was getreden, en dat dus, zoolang de anplantingen (d.i. in casu, de vrijwillige) wiet wareu afyeschreven, daarover niet willekeurig mocht worden beschikt."

Hieruit zou dus volgen, dan wanneer eene dessa vrijwillige aanplantiugeu aaulegt, deze dadelijk bet karakter bekomen van gouvernements-tuineu, en het haur dus uict vrijstuat ze weder te verlaten, Een wonderlijk denkbeeld van orijw llighuid' LCUN. 1879 . 
van den meester zich ovor ćéne aanplanting zou kunnen uitstrekken?

3 "Welk stelsel zou dan te verkiezen zijn, dat van publieke uitbesteding of van onderhandsche gunning."

Merkwaardig is het advies, dat de Raad ran Indië gegeven heeft op het verslag van den hoofdinspecteur der kultures.

Op de eerste vraag zegt de Raad: nnatuurlijk zou daarvan alleen sprake kunnen zijn dáár, waar de bevolking genegen mocht bevonden worden om vrijwillig afstand van hare rechten op de tuinen te doen, en zou er nimmer aan gedacht kunnen worden, om aan de eventueele huurders arbeiders te leveren, maar zouden zij daarin even als in het Samarangsche geheel buiten bemoeienis van het bestuur moeten voorzien.

„Met den hoofdinspecteur is de Raad het eens, dat let doen overgaan in handen van prrticulieren van zoodanige koffictuinen als te ver zïjn afgelegen, om met voordeel door de thans daarbij belrokken planters te worden angehonden, zeer is aan te bevelen, behoudens dezer geneigdheid om van die tuinen afstand te doen. Van eenen dergelijken maatregel zou de Raad zich overigens hoogere direkte voordeelen, dan door den hoofdinspecteur worden aangenomen (*), durven voorstellen, terwijl zoo als hij terecht opmerkt, de voor de planters tengevolge van het verlaten der tuinen vrij vallende tijd, door dezen zeer waarschijnlijk voor een groot deel aan de teelt van moenosoeko-koffie zal worden besteed, als wanneer voor de aan de particuliere overgelaten oogsten, eerlang anderen aan het gouvernement zullen toevalleu.... Orerigens is de Raad het geheel eens met de hoofdinspecteur, dat bij eene verhuring als de hierbedoelde, een huurschat in geld boven eene in natura te verkiezen is, al ware het maar alleen omdat daardoor meer veerkracht aan de bijzondere onderneming gegeven wordt."

Op de tweede vraag luidt het advies van den Raad van Indië ten gunste van eene verhuring in kleine perceelen, niet alleen omdat daardoor concurrentie bevorderd wordt, en dus ook het gouvernement de hoogste prijzen voor de tuinen kan bekomen, maar ook in het belang eener meer zorgvuldige teelt en bereiding, terwijl tevens zulk eene verhuring in kleipe perceelen 't aan inlanders gemakkelijk maakt om als huurders op te treden. Eindelijk merkte de Raad op, dat een zakelijk recht op de te verhuren tuinen en den grond een niet te ontkennen behoefte is ${ }_{n}$ ten einde

(*) Zie het Algeme'en Verslag van de uilkomsten van het onderzoek betreffende de kofiekulluur op Juva, bli. 170 volg. 
aan de particuliere ondernemers het door hen benoodigde crediet te verzekeren."

Eindelijk op de laatste vraag adviseerde de Raad van Indië in het roordeel van publieke vitbesteding.

Wij maken te eer van deze zienswijze van den Raad van Indië melding, omdat wij overtuigd zijn, dat men, wat vroeger of wat later, eindelijk tot de overgifte der tuinen aan de particuliere industrie zal moeten overgaan (*). Reeds nu is men begonnen de inlandsche industrie in de gelegenheid te stellen, de koffiekultuur in vrijen arbeid te drijven. Wel is waar wordt zij nog verplicht tot de levering van al de geproduceerde koffie, maar hiervan zal men gaandeweg terug komen, en eene pachtschat in geld gaan eischen. Met de particuliere industrie, indien zij eens eene werkelijke vlucht neemt, $\mathrm{nl}$. indien het gouvernement haar niet feitelijk onmogelijk maakt, kan de gouvernements kultuur niet wedijveren, noch in meer zorgvuldige en oordeelkundige behandeling en bereiding, noch ten opzichte van de arbeidsloonen. In de vrije industrie ligt de toekomst der koffiekultuur.

Gaarne zouden wij nog eene zaak, welke zeer nauw verwant is met de koffiekultuur, hier willen behandelen, ware 't niet, dat wij reeds nu vreesden de grenzen van ons bestek overschreden te hebben. Wij bedoelen de kwestie in hoever moerdere verkoop van de koffie in Indië al dan niet wenschelijk is, vooral in verband met de adressen van de Kamer van Koophandel te Batavia en die van de Kamers v. $K$. te Rotterdam en te Amsterdam. Wij hopen echter op dit punt in een later artikel terug te komen.

Ons bestek laat niet toe al de vraagstukken van de koloniale politiek door den heer Pierson in zijn uitstekend boek behandeld,

$\left(^{*}\right)$ Het schijnt, dat de regeeriug vroegrer ook gedacht beeft aau eeue verhuring der kuftietuineu aau particulieren. Inmers de Minister Fransen van de Putte zeide iu de zittiug van 27 . ei 1863 : "ik heb overwegingen vau miju unbtsvourgaugers gevonden, om de gouveruements-kofhietuinen te verhurcu aau particulieren, en ik geloof, dat dit voor de productie der kollietuiuen zeer wenschelijk en zelf́s in het belaug der Javanen zon zijn. Dit is uiet alleen mijn gevoelen, maar ik heb onder andere een rapport gevonden, dat niet suspect kan wezen, nl. van de lloogl. de Vriese," enz. (Hand. 2e Kam. 18621863 blz. 84il.) De Minister kon echter daartoe niet overgaan, omdat de Javaan bezitter van den grond is. Het komt ous echter vool, dat dit argument alleen dan afdoende zou zijn, wanneer de inlandsche bevolking haar recht op dien grond wil handhaven; daar waar zj genegeu mocht bevoudeu worden om afstand te doen van huar récht, zou dus verhuring van de kothetuiueu aun 1 articulieren geen bezwaar ziju. 
nategaan. Wij bepalen ons dan ook slechts bij enkele daarvan. Wij kunnen echter niet nalaten nog eenige oogenblikken te verwijlen bij de kwestie van het grondbezit.

In een merkwaardig hoofdstuk, nl. het VIIIe, getiteld „Een parallel", "treedt de heer Pierson in hoogst belangrijke, wetenschappelijke beschouwingen naar aanleiding van de werken van Nass, Maine, von Maurer, Lavalaye en anderen, over de primitieve toestanden van het grondbezit in Europa en in ons vaderland. Daarin vindt hij verscheidene parallellijnen met die, welke nog op Java gevonden worden, zoodat hij tot de conclusie komt: ${ }_{n} \mathrm{O}_{\mathrm{p}}$ Java zouden wij onze kindsheid terug vinden; Nederland zou een groot geworden Java zijn; de lijnen, waaruit Java's sociale toestand is samengesteld, wij zouden ze slechts doortetrekken hebben (rekening houdende met de bijzondere omstandigheden, waaronder ons volk is opgegroeid) om ons eigen beeld te herkennen" $\left({ }^{*}\right)$.

Hoe belangrijk ook die studie zij om den toestand van het grondbezit der bevolking te leeren kennen, wij kunnen ons daarin niet verdiepen. Onze taak is meer den actueelen toestand der inlandsche bevolking te beschouwen, en de middelen nategaan, dio kunnen leiden tot verbetering daarvan.

De voornaamste strekking der wet van 9 April 1870 (Ind. Stbl. no. 71), meer bekend onder den naam van de Agrarische Wet, is om in de voornaamste plaats het grondbezit der inlandsche bevolking te doen eerbiedigen. Doch daarbij regelt zij de bevoegdheid tot uitgifte van woeste gronden aan particulieren in erfpacht voor den tijd van 75 jaren $(\dagger)$.

Gaan wij eerst het laatste punt na. Vooraf echter eene algemeene opmerking. De verschillende koninklijke besluiten, die ter uitvoering van de agrarische wet het licht hebben gezien, zijn zoo talrijk en zoo door alle jaargangen van het Ind. Staatsblad verspreid, dat het inderdaad bijna onmogelijk is, om uit dat labyrinth zich te redden (§). Wenschelijk zou 't zijn, en herhaaldelijk

(*) Pierson, blz. 243.

(†) Op blz. 287 vau het werk van den Hr. Pierson ziju in de noot eenige misstellingen ingeslopen. 1. Het ur. van het Staatsbl., waaronder de wet van 9 April 1870 vermeld wordt, is niet 7 , maar $71 ; 2$. het kon. besl. van 16 April 1872 (Ind. Stbl. nr. 118) moet zijn 16 April 1870; 3. het kon. besl. vau 20 Juli 1870 (Stbl. 117) moet zijn 16 April 1872.

(\$) Dat zelfs ambtenaren, met de uitroering belast, daardoor bemoeilijkt worden, blijkt o, a. nit betgceu de heer inr. Levyssohn Normau in zijn bekend Rapport 
is er reeds op aangedrongen, dat al die verspreide verordeningen tot een geheel worden omgewerkt $(*)$.

De bevoegdheid tot uitgifte van woeste gronden in erfpacht is zeker een niet te miskennen stap ten goede. Verhuur van gronden werd reeds geregeld bij besluit van 3 Juli 1856 (Ind. Stbl. no. $64)$; doch vooreerst werd daarbij voor geen langer termijn dan van 20 jaren verhuurd, en ten andere, verhuur geeft geen zakelijk recht, hetgeen bij erfpacht wel het geval is, waardoor dus het kapitaal genegen wordt gevonden zich in landelijke ondernemingen te steken. Jammer echter, dat hier weder beperkingen worden aangebracht, die wel is waar het noodzakelijk gevolg zijn van de omstandigheid, dat de Staat een monopolie uitoefent, dat hem dwingt tot maatregelen, die ieder ondernemer moet nemen, doch die de uitgifte zeer belemmeren. Reeds boven sprekende over lke koffiekultuur teekenden, wij aan, dat bij elke aanvrage om gronden, nauwkeurig nagegaan wordt, in hoeverre die tuinen in de eerste tien jaren wellicht gebruikt kunnen worden voor de gouvernements-koffiekultuur, terwijl ook art 12 van het kon. besluit van 20 Juli 1870 (Ind. Stbl. no. 118), gewijzigd bij koninkl. besl. van 16 April 1872 (Ind. Stbl. no. 116), bepaalt, dat binnen een bij ordonnantie vasttestellen afstand van de gouvernentstuinen de teelt van koffie wordt verboden, zoodat die gronden dus niet kunnen worden uitgegeven voor particuliere koffietuinen $(\dagger)$. Zoover ons bekend is, heeft de in art. 12 bedoelde ordonnantie nooit het licht gezien; althans wij zochten te vergeefs er naar in het Ind. Staatsblad. Doch blijkens eene circulaire van den toenmaligen direkteur van binnenl. best. van den 30 Sept. 1875 wordt aan de residenten opgedragen bij elke aanvraag te onderzoeken, in hoever de ligging van het perceel aanleiding zou kunnen geven tot het onttrekken van gouvernements-koffie aan de verplichte levering (§). Het

over de agrarische aanyelegenheden mededcelt blz. $3:$ "velen (nl. ambtenaren), ook de meer ambitieuse, verklaarlen dat zij door de menigvuldige wijzigingen, dikwijls moeilijk den weg konden vinden in de agrarische verordeningen, en daarin te weinig oplossing vonden van vraagpunten, dic in de eerste plaats badden moeten zij̣n opgelost."

(*) Door den heer Levyssohu Norman is eene dergelijke verordening ontworpen en bij den Raad van Indië ingediend, doch eene besli-sing is nog niet gevalleu.

(†) Bij kon. besl. van $17 \mathrm{Juli} 1877$ (Ind. Stbl. nr 27 1 ) worden cenige afdeelingen en één district in de Preanger aangewezen, waur geene gronden worden uitgegeven.

(†) Zie Bijbl. tot het Ind, Stbl., d, XIV, blz, 222, 
wordt dus aan de individueele opvatting - de CommissarissenGeneraal zouden gezegd hebben, „aan de zinnelijkheid der residenten" - overgelaten welke die afstand moet zijn, hetgeen dus ten gevolge zal hebben dat die afstanden hier en daar zeer zullen verschillen (*). Eindelijk zijn, gelijk wij boven zagen, de woeste gronden om en bij de dessa's uitgesloten, omdat zij voor de eigene koffiekultuur der dessabevolking zouden kunnen worden gebruikt. Zoo zijn dus drie soorten van gronden ontoegankelijk voor de particuliere industrie.

En toch, de vestiging van het europeesch element in de binnenlanden is ook uit een politiek oogpunt van zeer groot belang, vooreerst omdat de ondernemers, die onafhankelijk zijn, in den regel de beste controleurs zijn van de handelingen van de gemeentelijke en plaatselijke besturen, en zij ook in tijden van woelingen gewichtige diensten kunnen bewijzen aan het gouvernement, getuige hetgeen in den Javaschen oọrlog heeft plaats gehad, en ten andere omdat hun voorbeeld ten goede komt van den inlandschen landbouw en de industrie "Met het volste recht", zegt een schrijver, met indische toestanden zeer vertrouwd, „mag de Europeesche industrie een onmisbare factor van Indiës ontwikkeling worden genoemd; zonder haar zou de landbouw der kolonie nog veel gebrekkiger, zouden de bemesting en irrigatie der gronden nog veel schraler, zou Indië nog veel armer, zou het lot der bevolking nog veel treuriger zijn" $(\dagger)$.

Op de conferentien, die de heer Levyssohn Norman gedurende zijne rondreizen op Java hield, werd ook de vraag besproken, over het al of niet wenschelijke om de uitgifte van gronden ook dan tegen te houden, als men ze benoodigd acht voor den eigen landbouw - en dus voor andere kultures dan die der koffie tengevolge waarvan de aanvraag zou moeten worden geweigerd, op de overweging, dat de uitgifte in strijd zou zijn met de belangen der bevolking, zoo als geschieden kan volgens art. 4 van het Staatsblad $1856 \mathrm{nr} 64$ bij verhuur van woeste gronden? Die vraag werd verschillend beantwoord. Men beriep zich o. a. op Kediri, Madioen en Bagelen, waar de bevolking - naaf men beweert - grootere waarde hechtte aan de alang-alangvelden dan aan sawahs. En daarom waren er die meenden, dat welke ook het voordeel moge zijn van de particuliere industrie, de

(*) De Hr. Pierson spreckt van eẹ kring van vięr uren gaans om de dessa (blz. 289).

(†) J, C, vall Kesterẹ, Hoe het in Indië gaat, bla. 87. 
uitgifte van gronden in zulke gevallen voor de bevolking nadee'ig zou kunnen zijn, en die dus aan het gewestelijk bestuur zouden willen overlaten te beslissen, in hoever aan de aanvraag gevolg zou kunnen gegeven worden. Men erkende echter dat men dan wel eens te strijden zou hebben met „overdreven individueele meeningen". Daartegenover stond het gevoelen van hen, die beweerden, "dat uitgifte van gronden aan particulieren op zich zelf reeds zulk een groot voordeel is voor de omwonende bevolking, dat de vraag of de grond wellicht benoodigd zou zijn voor de volkskultuur daaraan geheel ondergeschikt moet zijn. Vergeleek men toch het kapitaal, dat onder den inlander in omloop kwam door eene landelijke onderneming, de welvaart die daardoor bij schier alle klassen bevorderd werd door het bezigen van allerlei werkkrachten, welke tot nu toe onbenut waren, de toeneming van bevolking, de daardoor verhoogde prijs der landbouwproducten vergeleek men dit alles met de dikwijls luttele opbrenst van een sawah of tegalveld, dikwerf nog beplant met gewassen van luttel waarde, dan moet het belang van de bevolking gezien worden niet in de bebouwing dier velden door den aan zijn lot overgelaten inlander, maar in het dienstbaar maken van deze aan de particuliere kultures." Verder beweerden zij, dat indien het andere gevoelen aangenomen werd, het, in de hand van sommigen een middel zou worden om de particuliere industrie tegen te werken, een middel te gemakkelijker, omdat het geheel eene zaak is van localen aard, nog meer van individueele opvattingen" $\left({ }^{*}\right)$.

Wij erkennen gaarne, dat wij het laatste gevoelen zouden deelen, indien wij aan de bespreking hadden deelgenomen, omdat het zeker het meest getuigt van eenen verzienden blik, doch tevens verklaren wij dezen strijd van gevoelens niet recht begrepen te hebben. Bij elke aanvrage moet volgens no 2 van de wet van 1870 overwogen worden, of door den afstand van grond ook inbreuk worde gemaakt op de rechten der bevolking. Het kon. besluit van 20 Juli 1870 (Ind. Stbl. no 118), opnoemende welke gronden niet in erfpacht mogen worden uitgegeven, bepaalt dat daaronder vallen o. a. $n$ gronden, waarop anderen recht hebben, indien zij ongenegen zijn zich van hun recht te ontdoen "Welnu, een van beiden is waar: of de bevolking heeft recht op dien grond en is ongenegen om zich daarvan te ontdoen, of zij heeft geen recht. In het eerste geval kan de afstand geen plaats vinden, in

(*) Rapport over de agrar, aangelegenheden, blz, 13 volg. 
het laatste geval mag de uitgifte niet geweigerd worden. Wij zijn zeer ingenomen met het beginsel in de wet gehuldigd, dat de rechten der bevolking op hare gronden moet geeerbiedigd worden, maar indien men de zaak zoo ver gaat uitstrekken, dat ook zelfs buiten het rayon, dat voor de uitbreiding der dessa getrokken wordt, andere gronden in de nabijheid liggende, waarop de bevolking op het oogenblik geen rechten laat gelden, wellicht in de verre toekomst kunnen strekken in het belang der bevolking, dan gaat men te ver. Op die wijze zou men inderdaad de zaak te veel overlaten aan de vaak overdreven individueele opvattingen der residenten, die soms te weinig doordrongen zijn van het belang der industrie.

Volgens het bovengenoemd kon. besl. van 20 Juli 1870, gewijzzigd bij kon. besl. van 16 April 1872 (Ind. Stbl. nr. 116), worden de gronden bij openbare mededinging aangeboden - of wel zij worden afgestaan op aanvraag. $\mathrm{W}_{\mathrm{ij}}$ hebben nooit de ratio legis van de anbieding begrepen, tenzij de regeering daarmede eene soort van speculatie beoogde, om hoogere pachtsommen te bedingen; doch dan zou dat toch eene zeer slechte speculatie zijn; "het doel van den Staat is niet tegen hooge pachtsommen veel erfpachtsgronden uit te geven, maar in het algemeen belang woeste gronden bebouwd te krijgen, desnoods tijdelijk met opoffering van een gering direkt voordeel" $\left.{ }^{*}\right)$; in onze eenvoudigheid hebben wij altijd gemeend, dat de particulieren, die hunne kapitalen in landelijke ondernemingen willen steken, het best in staat zouden zijn, zulke gronden te kiezen en te vragen, die het meest geschikt zijn voor hunne ondernemingen. De uitkomst heeft tot dusver dan ook bewezen, dat van die aanbiedingen niet veel gebruik is gemaakt, terwijl daarentegen voortdurend een aantal perceelen zijn uitgegeven op aanvraag van de belanghebbenden $(\dagger)$.

"Dank zij de agrarische wet, is de uitgifte van woeste gronden in onzen tijd toegenomen", zegt de Hr. Pierson (§). Volgens hem waren in Augustus 1869 - dus vóór de invoering der agrar. wet, de uitgegeven perceelen slechts 71 in getal, een terrein van 38000 bouws beslaande. Volgens het onlangs uitgekomen Koloniaal Verslag over 1878 waren op het einde van 1877200 perceelen in de registers ingeschreven (**). Nu ontveinzen wij het niet dat, al

${ }^{*}$ ) Levyssohn Norman, Rapport over de agrar. aangelegenheden, blz. 9.

(†) Kol. Versl. 1878, blz. 96.

(s) Blz. 288.

(**) Kol, Versl. 1878, blz. 96 . 
moge dit eijfer van vooruitgang getuigen, toch de verwachting hooger gespannen was, bij de behandeling der wet van 1870 . Vooreerst zal te oorznak vermoedelijk daarin gezocht moeten worden, dat juist zulke gronden uitgesloten zijn, waar de ondernemer over voldoende werkkrachten kan beschikken, en ten andere zal men de teleurstelling ook voor een. groot deel moeten wijten aan het gemis aan vertrouwen van het kapitaal, dat uit Nederland naar ginds moest toevloeien. In hoever het voorschrift, dat de erfpachter voor eenen inlander of vreemden oosterling in zijnen dienst $f 5$ per jaar moet betalen „afgescheiden van de belasting op het bedrijf, rechtstreeks te voldoen door hen, die eenigen handel, eenig bedrijf, eenig handwerk of eenige nering uitoefenen, of van zoodanig andere belastingen, waaraan die bedrijven nader mochten worden onderworpen" (art. 14 al. 2), daarop van invloed is, durven wij niet beslissen. Zeker is het dat hierdoor de exploitatiekosten aanmerkelijk toenemen, doch daartegen is de op de onderneming gevestigde inlander vrij van kultuur- en heerendiensten.

Het overig gedeelte van de agrarische wet is grootendeels gewijd aan de rechten der inlandsche bevolking.

Ook hier vooraf eene opmerking: art. 1 van het kon. besl. van 20 Juli 1870 (Ind. Stbl. nr. 118) ter uitroering van de agrarische wet, zegt: "behoudens opvolging van de tweede en derde bepaling der voormelde wet, blijft het beginsel gehandhaafd dat alle grond, waarop niet door anderen recht van eigendom wordt bewezen, domein van den Staat is." Met dat beginsel kan de tweede bepaling der wet - „de Gouverneur-Gener. zorgt dat geenerlei afstand van grond inbreuk make op de rechten der inlandsche bevolking" - geheel illusoir worden gemaakt. Immers door dat beginsel wordt al de grond, waarop de inlander zijn eigendomsrecht niet kan bewijzen, tot staatsdomein verklaard. Dat bewijs kan de inlander niet leveren, want er bestaan geene registers van eigendomsbewijzen voor hem, en hij is niet onderworpen aan het Indisch Burgerl Wetboek. Wij weten wel, dat het gouvernement 't zoo nauw niet toepassen zal, maar 't neemt niet weg, dat door dat beginsel, de grondslag van het grondbezit der inlandsche bevolking .zeer precair is. En dat een dergelijk beginsel inderdaad tot gevaarlijke gevolgtrekkingen kan leiden, blijkt uit eene circulaire van den direkteur van het binnenl. bestuur van 17 Sept. 1872, waarin, naar aanleiding eener rechterlijke beslissing, welke het omkappen van koffieboomen door de inlanders niet strafbaar 
stelde, gezegd wordt, dat die jurisprudentio nu niet meer hondbaar is, nu het bovenvermeld beginsel is gehandhaafd en de Staat "onder bepaalde voorwaarden over den grond in gebruik bij de bevolking besclikl en dien beplanten doet" $\left({ }^{*}\right)$.

$\mathrm{Na}$ deze opmerking, zien wij verder hoe de rechten worden geëerbiedigd. Die rechten zijn meest gebruiksrechten. Over de bepaling, dat geenerlei afstand inbreuk maken mag op die rechten, spraken wij boven reeds. Eene andere bepaling zegt: „over gronden door inlanders voor eigen gebruik ontgonnen of als gemeene weide of uit eenigen anderen hoofde tot de dorpen behoorende $(\dagger)$, wordt door den Gouverneur-Generaal niet beschikt dan ten algemeene nutte op den voet van art. 77 van het Regeer.-Reglem. (\$), en ten behoeve van de op hoog gezag ingevoerde kultures volgens de daarop betrekkelijke verordeningen, tegen behoorlijke schadeloosstelling." Er wordt hier dus onderscheid gemaakt tusschen onteigening ten algemeene nutte, en die ten behoeve van de gouvernements-koffiekultuur. Tegen de eerste kan geen bezwaar bestaan; zij is een algemeen recht van den Staat; en in het tweede moet men berusten zoolang de gouvernements-koffiekultuur bestaat. Doch men heeft gevoeld, dat men daartoe niet zeer gemakkelijk mag overgaan, en bij besluit van den Gouverneur-Generaal van 30 Januari 1876 is bepaald dat over die gronden niet dan bij volstrekt yebleken noodzakelijkheid mag worden beschikt, en dat over de uit te keeren schadeloosstelling een nauwgezet onderzoek door den hoofdinspecteur der koffiekultuur, in overleg met de plaatselijke ambtenaren en inlandsche hoofden, en in verband met locale omstandigheden moet plaats hebben (**).

Het derde beginsel geldt het erfelijk individueel bezit van den grond.

(*) Zie Bijbl. tot het Ind. Stbl., deel XII, blz. 432 .

$(\dagger)$ "Onder gemeene weide wordt verstaan de grond, welke te dien einde voor het uitsluitend gebruik van een of meer dorpen is afgezonderd.

"Onder grouden uit andere hoofden tot het dorp behoorende, worden verstaan die welke door inlanders voor eigen gebruik outgonner en niet kennelijk verlaten zijn; de woonerven, de wegen, die ten laste zijn van het dorp; gewijde gronden; begraafplaatsen, de erven der moskeeën, en alle bimen de kom der dorpsgemeenten gclegen pleinen en andere openbare plaatsen; " art. 2, ordonn. v. d. G.-G. 7 Maart 1874 (Ind. Stbl. no. 79).

(9) Art. 77. "Niemand kan van zijn eigendom worden ontzet dan ten algemeene uutte op de wijze bij algemeene verordening bepaald " enz.

$\left({ }^{* *}\right)$ Bijbl, tot het Stbl., d. XITV, blz. 99 volg. 
Erfelijk individueel hezit is het hezit van grond door het individu - welke grond niet tot de gemeenschap van de dessa behoort - onverschillig of de persoon dien grond door ontginning, erfenis koop, of schenking heeft verkregen. Hij is geen eigenaar, maar heeft slechts een gebruiksrecht. Het erfelijk individueel bezitrecht is een echt inlandsch begrip. De grond behoort volgens de opvatting van den inlander den Souverein toe, en hij heeft slechts het genot, het gebruik er van $\left(^{*}\right)$; hij kan het na doode aan zijne erfgenamen nalaten, het vervreemden - wegschenken of verkoopen - maar het bezit is precair, onzeker omdat het zou kunnen gebeuren, dat de Souverein het hem ontneemt.

Wij zeiden, dat de inlander het bezit van den grond ook kan verkrijgen door ontginning. Daarvoor zijn regelen voorgeschreven. Want niet elke ontginning kan hem dat recht schenken; den zoogenaamde roofbouw door zwervende ontginners ondernomen, die nu hier, dan ginds ontginnen, om den pas ontgonnen grond spoedig weder te verlaten, wilde men tegengaan $(\dagger)$, daarom wordt voorgeschreven, dat hij die ontginnen wil, vergunning vragen moet of van het hoofd van het gewestelijk of van het plaatselijk bestuur of van het districtshoofd, naar gelang of van den aard van het terrein (djatibosch, wildhout of nipabosch), dat hij ontginnen wil, of wel naar gelang van de ligging dier gronden. Ook zijn aan de vergunningen eenige voorwaarden gehecht, zoo wel betrekkelijk den tijd, waarin de grond in bebouwing moet zijn gebracht, als het aanbrengen van grensteekens en behandeling van hellende terreinen; zijn aan al de voorwaarden voldaan, dan is de verkrijger erfelijk individueel bezitter van den door hem ontgonnen grond (§).

De regeling van het ontginningsrecht achten wij in vele opzichten zeer gewenscht. Jammer dat de ordonnantie, blijkens het koloniaal verslag 1878 nog zoo slecht wordt nageleefd on ${ }_{n}$ dat in

(*) Zoo is het ook in Hindostan. Zie Pierson, blz. 267.

( + ) Volgens den hecr Levyssohn Norman wordt in de Soenda-lauden de roofbouw zeer juisi in het volgende vertalde versje gesehetst:

"De stijlen (van de but) van wilde bamboe,

Het dak van losse bladeren,

Een jaar verblijf

En dan er van door."

Rapport, blz. 47 .

(\$) Zie ordun, vau den G. -G, 7 Maart 1874, (Ind. Stbl, no, 7J). 
eon aantal districten nog steeds door de bevolking geheel willckeurig over de woeste gronden wordt beschikt, en dat de voor Java's toekomst zoo gevaarlijke rooflouw nog in het minst niet beperkt is" $(*)$.

„Grond, door inlanders in erfelijk individueel gebruik bezeten, wordt, op aanvraag van den rechtmatigen bezitter, aan dezen in eigendom afgestaan onder de noodige beperkingen, bij algemeene verordening te stellen, en in den eigendomsbrief uit te drukken, ten aanzien van de verplichtingen jegens den lande en de gemeente en van de bevoegdheid tot verkoop an niet-inlanders", aldus bereelt de wet van 9 April 1870. Een kon. besluit van 16 April 1872 (Ind. Stbl. 117) schrijft de procesorde daarover voor. Het is de landraad, die op dergelijke aanvragen beslist. Voordat de rechter het verzoek toewijst, moet de aanvraag tweemalen, telkens met een tijdsverloop van zes maanden aangeplakt en afgekondigd worden. Iedereen, die rechten meent te hebben op het perceel is bevoegd, om negen maanden na de eerste en drie maanden na de tweede aankondiging zich tegen de toewijzing te verzetten; de rechterlijke beslissing kan dus eerst na dien tijd geschieden.

De zorg van den wetgever voor de belangen der rechthebbende gaat hier inderdaad te ver. In het meergenoemd rapport van den heer Levyssohn Norman wordt dan ook met even zoovele woorden gezegd: $n$ het koninklijk besluit van 16 April $1872 \mathrm{Nr}$. 29 (Ind. Stbl. $\left.n_{0} .117\right)$, betreffende vervanging van inlandsch erfelijk individueel grondbezit door eigendom, was in de meeste streken eene doode letter" $(\dagger)$.

$\mathrm{Om}$ - in 't voorbijgaan - een staaltje te geven, hoe de formule, die onder schier alle kon. besluiten en ordonnantien gevonden wordt: , en opdat niemand hieraan onwetendheid voorwende, zal deze.... voor zooveel noodig in de inlandsche en chineesche tulen aangeplakt worden." - toegepast wordt, vermelden wij hier, hetgeen door den heer Levyssohn Norman wordt medegedeeld, dat dergelijke documenten soms ten onderste boven worden aangeplakt, of wel zoo hoog dat een gewoon sterveling niet bij machte is ze te lezen, zoodat de algemeene bekendheid bij de bevolking al zeer weinig te beteekenen heeft (§).

${ }_{n}$ Doch ook daar, waar de maatregel bekend was, vond men

(*) Kol. versl. 1878, blz. 96.

(†) Blz. 18.

(\$) Blz. 19. 
weinig opgewektheid om er de zegeningen van te genieten ", zegt de Hr. Levyssohn Norman (*). De oorzaken daarvan moeten gezocht worden in de moeite en vooral in de kosten, verbonden aan het verkrijgen van een meetbrief, en in de procedure bij den landraad en haren langen duur. "Het was aller opinie, dat de inmenging van den landraad onnoodig en belemmerend was. Onnoodig aangezien het hier geen twistgeding over hel mijn en dijn geldt, maar in de meeste gevallen met zekerheid kan worden gezegd, wie de rechtmatige bezitter is, terwijl bovendien de landraad, zoodra er geen verzet is, alleen op de verklaring daarvan, het verzoek moel toewijzen, zonder zelf eenig onderzoek in te stellen; belemmerend, daar de inlander in de meeste streken huiverig is, om voor den landraad te verschijnen, met andere woorden in eene "perkara" gewikkeld te worden. Dat de noodeloos lange termijnen, waartegen algemeen te velde werd getrokken, belemmerend zoude werken, werd reeds door de agrarische commissie voorzien" $(\dagger)$.

Maar zijn dan, zal men vragen, aan het eigendomsrecht geene voordeelen verbonden, welke al die bezwaren overtreffen? Geenzins. De van erfelijk individueel bezitter tot eigenaar gepromoveerde inlander blijft onderworpen aan de betaling van landrente, aan heerenen kultuurdienstplichtigheid; hij moet den grond, waarvan hij eigenaar is, als het gouvernement het vordert afstaan ten behoeve van de koffiekultuur, of, plant hij zelf koffie, dan is hij verplicht de verkregene vruchten tegen een door het gouvernement bepaalden prijs af te lveren. Bovendien mag hij dien grond niet vervreemden aan niet-inlanders. Waarin verschilt nu dat eigendom van het erfelijk individueel bezit? Het eenige verschil is dat de eigenaar zijn grond mag verhuren aan niet-inlanders voor den tijd van 20 jaren; de erfelijk individueel bezitter voor niet langer dan 5 jaren (\$). "Waarom is het woord eigendom in de wet gebracht", vraagt de heer Pierson, „hetgeen ten gevolge heeft gehad, dat thans in Indië verschillende benamingen worden gegeven aan rechtstoestanden, die schier in ieder opzicht aan elkander gelijk zijn? of wel, indien men er prijs opstelde het woord eigendom te bezigen, waarom is dan niet gehandeld naar het voorbeeld van den ontwerper der kultuurwet (de heer Fransen van de Putte), en allen

(*) Rapport, blz. 19.

(†) Ibid. 20).

(i) Zie ordonn. v. den G.-G. 30 Oet. 1871 (Ind. Stbl. nr 163). 
grond tot eigendom gemaakt; de onverdeelde tot eigendom der gemeente, de andere tot eigendom der individueele bezitters? Er heerschte al genoeg begripsverwarring ten aanzien van het Indisch grondbezit. Waartoe ze nog vermeerderd" (*)? „De inlander”, zegt de heer Levyssohn Norman, "ziet niet één voordeel in den verkregen eigendom. De lasten blijven dezelfde. Hoe zou hij in dergelijke omstandigheden neiging gevoelen om zijn bezit te vervangen door eigendom? De inlander blijft in hetzelfde rechtsverband als vroeger; alleen zal zijn bezit voortaan eigendom heeten en gewaarborgd zijn door schriftelijke titels. Hij is tevreden met zijne bezitrechten; hij is veilig met zijne bezitrechten; waarom zou hij verlangen naar een zoo beperkt recht van eigendom als hem dus het kon. besl. van 16 April 1872 wordt toegedacht" ( $\dagger$ ). Al die moeilijkheden en al die beperkingen zijn daarom te eerder te betreuren, „omdat de regeering niet mag nalaten wat den individueelen bezitter kan versterken in de overtuiging: de grond is mijn en het gouvernement eerbiedigt mijne aanspraken daarop. Ook is het ter beslechting van geschillen over grondbezit, bv. van vraag of een veld aan de gemeente of aan een der leden toebehoort, van veel belang dat de individueele bezitters van schrif. telijke titels zijn voorzien" (\$): Al de koloniale verslagen van 1874 af tot het laatst ingediende, nl. van 1878 zijn op dat punt eenstemmig, dat de aanvragen om conversie in eigendom zeer onbeduidend zijn.

Wat ook de agrarische wet heeft geregeld, over eene zaak bewaart zij het stilzwijgen, nl. over de bevoegdheid om de communale gronden in individueel bezit te converteeren. Dat communaal bezit is de oudste vorm van grondbezit. Het is wat nu nog ten onzent de mark is, of ook de meente, m. a. w. de gemeentegronden, die vermoedelijk uit de mark hun oorsprong hebben genomen, gronden waarvan alleen de markgenoten of de gemeenteleden gebruik kunnen maken (**).

Reeds du Bus drong in zijn bekend, boven door ons aangehaald, rapport aan op verdeeling dier gemeenschappelijke gronden en op

(*) Blz. 292 volg.

(f) Rapport blz. 21 volg.

(\$) Pierson, blz. 293.

(**) "Meu kau veilig aanuemen ", zegt de Hr. Piersou, blz. 276, "dat de mark vroeger in alle landen van Europa de meest algemeene vorm vau grondbezit is geweest, even als zij bet nu nog is op Java en in lliudustau." 
conversie in individueel bezit. De Minister Fransen van de Putte was na du Bus de eerste, die het voorstel deed om tot de verdeeling der communale gronden overtegaan. "De gemeenschappelijke dessa- of gemeentegronden worden tusschen de rechthebbenden verdeeld zoodra de meerderheid van hen het verlangt. Aan iederen verkrijger wordt van den hem toebedeelden kavel een eigendomsbewijs uitgereikt" (art. 9). Een zeer mild voorschrift, misschien in zoover te mild, dat het beter ware geweest de verdeeling als regel te stellen, en de handhaving van het gemeenschappelijk bezit alleen bij uitzondering te behouden, in bijzondere gevallen, met goedkeuring van den Gouverneur-Generaal. Doch, gelijk bekend is, werd deze wet ingetrokken, en is de kwestie van de conversio van communale gronden in individueel bezit gebleven in hetzelfde stadium, totdat men bij de behandeling van de agrarische wet tot de conclusie kwam, dat niets belette die verdeeling ook zonder uitdrukkelijke sanctie door de wet te doen plaats hebben. Doch de ervaring heeft geleerd, hoe jammer het is, dat de kwestie niet $\grave{a}$ fond is bediscussieerd en eene beslissing is genomen. Want ${ }_{\eta}$ is er eon Minister aan het bewind, die gunstig denkt over den individueelen eigendom, dan worden er naar Indië voorschriften gezonden, waaruit die gezindheid blijkt; is er een Minister, die anders daarover denkt, dan worden dezelfde voorschriften ingetrokken" $(*)$. Nauwelijks was de heer Levyssohn Norman door het Indisch gouvernement met eene missie, die met de conversie $v a n$ communaal bezit in nauw verband stond, op reis gezonden door Java, of er werd uit Nederland order gegeven om die reis te staken.

Te eer is te betreuren, dat de wet daaromtrent geene voorschriften inhoudt, omdat er een groot onderscheid bestaat tusschen hetgeen de heer Fransen van de Putte wilde in zijne kultuurwet en het overlaten aan het welbehagen der dessa's om de communale gronden al dan niet te verdeelen. Immers volgens de kultuurwet zou ten gevolge der verdeeling ieder deelgerechtigde dadelijk den eigendom bekomen. Wordi de verdeeling overgelaten aan de dessa's, dan krijgt ieder geërfde slecht het erfelijk individueel bezit, en om den eigendom daarvan te verkrijgen, moet hij de lange procedure volgen, waarover wij zoo even hebben gesproken.

Aan het communaal bezit paren zich onmiskenbare nadeelen. Vooreerst is daarvan een noodzakelijk gevolg eene gedurige verwisseling van gronden onder de deelgerechtigden. En juist die gedurige

(*) Piersoll, bl\%. 295. 
verwisseling - onverschillig of zij jaarlijks dan wel om de 2 of 3 jaren plaats heeft - maakt dat niemand belang heeft bij eene goede bearbeiding van den grond, die na zekeren tijd in handen van anderen vervalt. Welk belang heeft de gebruiker aan eene deugdelijke behandeling? Als de grond slechts zooveel opbrengt als de gebruiker voor zijne nooddruft noodig heeft, is hij tevreden. Van eenen intensieven landbouw, van eenen landbouw gedreven op groote schaal, kan dus geene sprake zijn. Reeds du Bus wees er op, toen hij van het gemeenschappelijk bezit zeide dat het is, "alleen voldoende om den landbouw in iedere uitbreiding, die hij ondernemen mag, te dooden." - "Kau men zich verwonderen," vroeg hij verder, "dat alles den ouden slender gaat? Dat de Javaan van het eene geslacht op het andere hangen blijft aan zijne oude rijstkultuur, en van geene andere weten wil? Ja, daar die rijjstkultuur zelfs weinig meer afwerpt dan wat de bevolking voor hare eigene voeding behoeft" $\left({ }^{*}\right)$ ? Voeg daarbij dat het dessabestuur, dat mede deelgerechtigd is, er wel voor zorgen zal, dat het steeds de beste gronden voor zich behoudt, zoodat de andere deelgenooten daarmede nooit voordeel kunnen doen. „Gesammt Gut, verdammt Gut" zeggen de Duitsche boeren ( $\dagger$ ), en zij hebben gelijk. Kapitaalvorming heeft geene plaats; alle deelgenooten blijven eeuwig en altijd even arm en nooddruftig, terwijl ook verdeeling van arbeid, zoo noodzakelijk in iederen socialen toestand vall zelf uitgesloten blijft. Maar er is meer; men heeft het communaal bezit verdedigd als het middel om het proletariaat tegen te gaan. Hoe? de toestand van een dessagenoot van ! of hoogstens een morgen gronds, die daaruit in de levensbehoefte van hem en zijn gezin moet voorzien, zou niet veel minder zijn, dan die van een proletarier? Men houde in het oug, dat, gelijk wij boven zagen, daar waar de druk van heeren- en kultuurdiensten zwaar zijn, de deelgenooten er op uit zijn, steeds nieuwe deelgenooten aan te werven om den druk beter te verdeelen, waardoor dus de aandeelen van den grond al kleiner en kleiner worden (§). Juist dat gemeenschappelijk bezit, dat het individu machteloos maakt om zijne positie te verbeteren, bevordert eene zekere zorgeloosheid die het proletariaat in de hand werkt. Merkwaardig is dan ook het door den heer Pierson aangehaald getuigenis van Anatole Leroy Beaulieu, "die zich niet

(*) Zie boven Liconomist 1578, blz. 827.

(†) Piersou, blz. 298.

(\$) Levyssohn Norman zegt, dat die aandeelen soms tot id bouws ingekrompen zju, bla. 52. 
als onvoorwaardelijk tegenstander van het communaal bezit doet kennen", in de Revue des deux Mondes van 15 November 1876: ${ }_{n}$ On doit remarquer, qu'en prenant le mot de prolétaire dans son sens étymologique, producteur d'enfants, rien n'encourage plus le prolétariat que le système communiste, qui donne une prime aux nombreuses familles. Par là aussi, en enlevant aux parents une grande part du souci que donnent naturellement les enfants, le communisme agraire peut indirectement encourager le prolétariat, dans le sens économique du mot, car, le sol étant restreint, ce régime risque d'amener à une multiplication des hommes plus rapide que la multiplication des moyens d'existence ou de bienêtre" $\left(^{*}\right)$. Verder haalt de heer Pierson aan het verslag van de Enquête Agricole betreffende Algiers, Oran en Constantine, waarin gesproken wordt van een verzoekschrift van een ruim zevenhonderd tal ingezetenen van Algiers, die rragen: "que l'on constitue la petite propriété, par laquelle la famine sera écarté" ( $\dagger$ ).

Eindelijk vergeten wij 't niet, dat daar waar armoede en nooddruft bestaan, ook alle prikkel voor geestes ontwikkeling gemist wordt. Zoo lang dus het communaal bezit gehandhaafd wordt, zal de intellectueele ontwikkeling achterlijk blijven.

Bij het bekrompen landbezit, ten gevolge van de gemeenschap der gronden, en het gemis van eenigen prikkel om de grond beter te bebouwen, bij de zekerheid dat het gebruikte perceel binnenkort hem ontnomen wordt, is ook de verbouwing van andere kultures voor den inlander eene volstrekte onmogelijkheid. Hij mag op zijn erf al wat koffie planten, voor andere kultures, die hij zonder moeite zou kunnen verbouwen, indien hij eigenaar ware, ontbreekt hem de gelegenheid, terwijl de rijstbouw eveneens veel te wenschen overlaat.

Daartegenover staan de voordeelen van individueel eigendom, ul. eene betere bewerking van den grond (§), omdat de inlander dan weet dat die van hem is, en van hem blijft; eene betere verdeeling van den arbeid zal eveneens het gevolg zijn van individueel bezit, daar de niet voor den landbouw geschikte zijn perceel ver-

(*) Pierson, blz. 299, die ook van dat gevoelen is, zie noot 1. op blz. 75: "llet commuuaal bezit - ziedaar juist ee» zijner schaduwzijden - geeft een veel te sterken prikkel aan de nitbreiding der bevolking."

(†) Ibid. blz. 305.

(乡) "Opmerkelijk was het ", zegt het Koloniaal Ver'slag 1878, "dat in die dessi's waar de conversie is tot stand gekomen, de gronden beter bewerkt eu bemest werdeu dan elders." Bl\%. 92. 
koopen of verhuren, en zich wijden kan aan die bedrijjen, wanrvoor hij meer aanleg en roeping heeft. Hij, die op die wijze, behalve van zijne eigene velden, nog eigenaar of pachter wordt van die zijns buurmans, kan en zal ook op meer breeden schaal den landbouw drijven, of wel hij verbouwt er producten, die hij aan belanghebbenden verkoopt voor de markt in Europa. Van den inlander zal hetzelfde gezegd kunnen worden, wat de Gouverneur van Britsch Indië, sir Bartle Frère van Hindostan zeide, dat de inlander op die gronden prijs stelt als op zijn leven: not only occupied, but valued as their lives $\left({ }^{*}\right)$. Kapitaalsvorming heeft plaats en dus de arbeidzaamheid zal toenemen. Ook de sociale toestand zal verbeteren; orde en veiligheid zullen toenemen; terwijl ook de invloed die het individueel bezit op het dessabestuur moet uitoefenen, niet zal achterblijven.

En nu meene men niet, dat het individueel bezit zoo onbekend is op Java. Reeds in ons vorig artikel is een beroep gedaan op het Eindresumé van het onderzoek naar de rechten van den inlander op den grond op Java en Madura, waaruit blijkt dat in verseheidene gewesten reeds individueel bezit bestaat $(\dagger)$, alsmede op het zoo genaamd communaal bezit met vaste aandeelen, ten gevolge waarvan de periodieke verdeeling heeft opgehouden, en dat dus zeer weinig verschilt van het individueel bezit (\$).

Ook de minister van Goltstein heeft niet kunnen ontkennen niet alleen, dat reeds lang individueel bezit bij de inlandsche bevolking plaats heeft, maar ook dat conversie van communaal in individueel bezit reeds jaren lang, vóór dat de aandacht hier te lande er op gevestigd was, zonder eenige tusschenkomst des bestuur plaats had gevonden, en wel van zelve, nl. door de verdeeling onder de deelgenooten niet te doen plaats hebben $\left({ }^{* *}\right)$. Maar ook uit het rapport van den heer Levyssohn Norman blijkt, dat

(") Pier'son, blz. 308 .

(†) Na dicn tijd zijn de resumis vau de nitkonsten betrekkelijk bet zelfde onderzoek in de buitenbezitlingen uitgekomen.

(\$) Zie ons artikel in de Éronomist 1878, bla. 829 volg. Tn het kol. Versl. 1878 wordt blz. Y2 van dat communaal bezit met vaste aandeclen gezegd, dat het viij wel gelijk stat met individteel "loch niet erjelijk" bezit, terwijl in het hol. versl. 1870 gezegal wordt, dat iuler individueel bezitter ziju leven laug hetzelide groudsiuk behondt, co dat dic groud na zijn dood aan zijne kinderen of bluedverwanten wordt loebedeeld", blz. 79. De bezitter kan ur dus niet over beschikken daariu ligt let verschil met "crlelijk individucel bezit."

(") Lil.ing 7 Nor. 187t. 1land. der 2e kamer, zitting 1874/75, bla. 70, volg. 
daar waar bij de invoering van de dwang-kultures het individueel bezit in communaal bezit werd geconverteerd, de ingezetenen der dessa bij de opheffing der kultuar, weder teruggekeerd zijn tot den vorigen toestand. Zelfs schijnen er streken te zijn, waar geen sporen te ontdekken zijn van een primitief communaal bezit $\left({ }^{*}\right)$.

Tegen de toekenning van het individueel bezit aan den inlander heeft men als een gevaar voorgesteld, dat hij, die weinig behoeften kent, die gesteld is op uiterlijke tooi en sieraden, al zeer ligt het hem toebedeelde perceel aan den een of ander speculant al is hij zijn landgenoot - zal verkoopen. Het op die wijze verkregen geld zal weldra verteerd zijn, en het gezin is niet alleen doodarm, maar het is daarbij overgegeven aan allerlei willekeur. $W_{i j}$ ontkennen niet, dat dergelijke voorbeelden zullen ontbreken, want zij hobben ook hier te lande in onzen meer algemeen ontwikkelden toestand plaats. Maar moet die vrees ons tegenhouden? Zal men een knaap zijn mes ontnemun, uit vrees dat hij zich kwetsen zal? Moge al zulke gevallen plaats hebben, de inlander is zoo kinderlijk niet, dat hij niet wejdra de waarde van zijnen grond zal leeren kennen. Het kan gebeuren, dat invloedrijke hoofden, op uitbreiding van landbezit belust, zich van vele gronden weten meester te maken; doch wat zal dan plaats hebben? De zoogenaamde kleine man zal pachter worden. Is die toestand zoo verkeerd? Indien wij toch nagaan, wat in vele landen plaats heeft, waar het communaal bezit vervangen is door verdeeling tusschen de geërfden, waar ook ophooping van landbezit in handen van weinigen het gevolg is geweest van de overdracht van kleinere perceelen, en waar ook van lieverlede dc vroegere eigenaar pachter werd van zijn eigen perceel, om van het kapitaal dat hij door verkoop er van had verkregen, het bedrijfs-kapitaal te maken ten einde met meer zorg zijn landbouw te kunnen drijven, dan hebben wij ook gezien, dat het nageslacht van den vroegeren pachter eindelijk weer op zijne beurt eigenaar werd. Zou dat ook niet het verloop zijn van de zaken op Java, als het communaal bezit in individueel bezit wordt geconverteerd?

Aan de conversie zullen bij uitvoering zeker wol eenige bezwaren verbonden zijn. Zoo zal b. v. de vraag wie deelgerechtigde is, hier en daar moeilijk te beslissen zijn. Er zullen regelen voorgeschreven moeten worden, en bet blijkt uit de koloniale verslagen, dat de indische regeering daarop reeds lang bedacht is geweest. Nu is hec

(*) Rapport, Wlz. 52, 53 . 
bekend, dat men in Indië doorgaand zeer lang overweegt. Toch schijnt het zijne goede zijde te heblen, dat men de materie goed kemne vóór en aleer men regels geve voor de uitvoering. In het laatste Koloniaal Verslag wordt gezegd dat de indische regeering in geen geval eene beslissing wilde nemen zonder nader onderzoek b. v. ,in hoeverre de tegenwoordige economische toestanden op Java hier en daar aan de oplossing van het communaal bezit in den weg staan; welke andere oorzaken de conversie belemmeren, en hoe die belemmeringen zijn weg te nemen; welke misbruiken bij het tot stand brengen der conversie kunnen voorkomen; in hoever de bevolking zich door vrees voor zoodanige misbruiken van de conversie laat terug houden; op welke wijze die misbruiken kunnen worden geweerd; welke voorzieningen (vooral met het oog op het ver.Jand tusschen kultuur- en heerendiensten en grondbezit) noodig zijn, om te weeg te brengen, dat noch de bevolking, noch het gouvernement schade lijdt." Omtrent dit alles wenscht de Indische reyeering ingelicht te zijn, voor zij een beslissing neemt $\left({ }^{*}\right)$. Uitstekend! doch niet genoeg kunnen wij den raad geven, overweeg niet al te lang; overweeg niet zoo lang, dat de nadeelen uwer langdurige overweging verre overtreffien de voordeelen eener spoedige beslissing.

Nog één woord. Over 't algemeen zijn zij, die de indische maatschappij kennen van ourdeel; dat de bevoegdheid om gronden aan niet-inlanders te verkoopen niet - althans nog in langen tijd niet - aan den inlander moet worden verleend. De Hr. Piersou is dat gevoelen niet toegedaau. Vooreerst wordt volgens hem de concurrentie veel meer bevorderd, wanneer ook Europeanen navraag doen uaar land, dan wanueer alleen inlanders als koopers kumneu optreden. Bovendien zou er een bepaald voordeel ingelegen zijn, omdat deze dan uit het voorbeeld vau den Europeeschen landbezitter zien wat de resultaten zijn van eene kultuur, waarbij partij getrokken wordt van de laatste uitkomsten der wetenschap. De Javaansche boeren zullen dan leeren van den Europeeschen kiupitalist, die in huin mıdden het landbouwbedrijf uitoefent $(\dagger)$. $W_{\text {ij }}$ scharen ons voor shands meer aan de zijde van hen, die bezwaar maken rooralsnog aan den inlander het recht te verleenen hunne gronden aan den Europeaan te verkoopen. Het belang dat deze heeft, um gronden machtig te wordeu, is grooter dan van dem

$\left(^{*}\right)$ kiul. Versl., 1878, blz. 93.

(†) Piersua, b1\%. 318. 
inlander; en zoo ligt worden lan allerlei middelen gebezigr, om den Javaan over te halen tot overdracht van zijnen grond voor eenen veel geringeren prijs, dan hij waard is. Ook de kultuurwet van den heer Fransen van de Putte durfde die bevoegdheid niet dadelijk te verleenen. $\mathrm{Z}_{\mathrm{ij}}$ schreef eene herziening dier bepaling na vijf jaren voor, en daarin zouden wij geen bezwaar hebben. Eerst moet de inlander zijne rechten leeren kennen en waardeeren.

Dat het op den duur wenschelijk is, dat ook de Europeaan eigenaar kan worden van het vaste goed van den inlander behoeft geen betoog. Zoolang dat niet geschieden kan, zal de inlandor ook geen gelden op hypotheek kunnen vragen van den Europeaan, omdat deze daartoe ongenegen zal zijn, daar hij gevaar loopt zijn kapitaal te verliezen bij wanbetaling van zijnen indischen dehiteur. Kan daarentegen eenmaal de inlander van den Europeaan hypotheek bekomen, wij meenen, dat zulks een groot voordeel voor zijne welvaart zou zijn.

Wij eindigen onze beschouwingen over de conversie van het communaal bezit met eene aan Pierson's werk ontleende aanhaling uit het boek van van den Bosch over onze kolonien in 1818 geschreven. "Het is niet te ontkennen, dat inrichtingen gelijk die, welke op Java bestaan, waarbij de inwoner wel in eene ruime mate het noorlwendige geuiet, maar door welke tevens de nitbreiding zijner bezittingen zoo goed als onmogelijk wordt gemaakt, ten volle de strekking hebben om zijn afkeer van den arbeid, zoo eigen aan den lande onder een verzengde luchtstreek to doen voortduren, en zoo wel de ontwikkeling der geestvermogens als der physische krachten van den mensch te stremmen. Dan, zal men hierin verandering beproeven, het is zeker, dat die op de vrije keuze van den Javaan behoort gegrond te zijn; en dit kan thans geschieden.... door de kultures met vrijwilligen arbeid verder uit te breiden, "n den Javann in de grlogrnheid le slellen om ool desmerkirzende arondeigenarr te corden" (*).

Hier nemen wij afseheid van het werk des heeren Pierson. Gaarne zouden wij nog eenige andere punten nit zijn belangrijk loek behandeld hebben, o. a. de landrente; doch vooreerst hebben wij de grenzen van een tijdschrift artikel al zeer ver overtroffen, en ten anderen worden, bljjkens het koloniaal verslag van 1878 , verscheidene ontwerpen bij de Indische regeering overwogen, en

$\left.{ }^{*}\right)$ Pierson, blz, 320, 
weet men nog niet welken weg men moct opgaan. Zooveel is zekcr dat de regeling van 1872 zeer vele bezwaren heeft. De ontwerpen der verschillende autoriteiten kunnen, bij onbekendheid er van, aan geene kritiek worden onderworpen. Daarom gaan wij dus liever dat punt met stilzwijgen voorbij.

Wij nemen - zeggen wij - afscheid van het werk des heeren Pierson, niet van hem zelven. Wij huldigen in hem den echt wetenschappelijken strijjer van de liberale koloniale politiek. Moge het hem gegeven worden nog dikwijls het in indische vraagstukken belangstellend publiek op dergelijke degelijke werken te vergasten. den Haag.

L. Ed. L.

P. S. Toen het I stuk van het artikel "Eenige holoniale vraaystuklken ran deu dag" in den vorigen jaargang van den Economist was afgedrukt, was het werk van mr. P. Mijer, getit. I. C Baud geschritst, nog niet in het licht verschenen, althans den schr. van het artikel niet ter hand gekomen. Eene nalezing zal men ons wel ten groede willen houden.

Blz. 618 regel 12 en 11 v. o. "Het blijkt uit een en ander dat de Commiss. Gener. 't goed voor haclden met de bevolking." De heer Mijer haalt uit eene buitengewone Batav. Cour. van $18 \mathrm{Jan} .1819$ het volgende zeggen van Elout aan: ${ }_{n}$ Het vaderland heeft aanspraak op een ruim genot van de voordeelen, welke deszelfs buitenlandsche bezittingen opleveren; maar het vaderland verlangt niet, dat de bevolking dier bezittingen bij uitsluiting tot bezorging van die voordeelen worde dienstbaar gemaakt. Het wenscht en wil, dat zij zelve daarin haar deel erlange Het vaderland wil nog meer; het staat ook aan vreemden toe, dat zij vruchten in onzen tuin plukken, mits zij onzen grond niet omwroeten, noch met onkruid bezaaien." (Mijer blz. 96, volg.)

Blz. 819 reg. 2 v. b. "Er was gebrek aan personeel," lees: naan bekwaam personeel" Vergelijk hetgeen Baud zegt: „de meeste ambtenaren konden zich met hunne gedachten niet begeven buiten den kring hunner dagelijksche bezigheden, en zelfs over zaken: die hun gemeenzaam waren, getuigden hunne oordeelvellingen van geheele onbelezenheid en verre. gaande bekrompenheid.... $\mathrm{Bij}$ het uitzenden van personen voor den burgerlijken dienst werden bij de bewindhebbers 
veelal slechts de omstandigheden, zelden de bekwaamheden der benoemden in aanmerking genomen.

"De meeste indische dienaren waren als soldaten, matrozen of hooploopers in den dienst der Compagnie getreden, en hadden zich langzamerhand den weg tot de hoogste ambtem gebaand. . . . Eene andere bijzonderheid, die niet onopgemerkt kon blijven, was de schier onbepaalde toelating van vreemdelingen in alle vertakkingen van de dienst." (Mijer blz. 65, zie ook blz. 110.)

Blz. 8:4 reg. 15 v. b. „Findelijk heeft de gebreklige staatsboekhouding" enz. Vergelijk Mijer blz. 152: "Deze moeilijkheden werden vermeerderd door eene achterstallige boekhouding, welke van der Capellen meer dan iets anders kwelde, omdat zij eenen slechten dunk van zijne zorg voor een ordelijk en regelmatig bestuur moest verwekken. En toch heeft het hem daaraan nooit ontbroken, blijkens de talrijke waarschuwingen en herinneringen, deswege aan de hoofdambtenaren, met de boekhouding belast, gericht. .... Men was tijdens het vertrek van Baud $\left(^{*}\right)$ nog niet gereed met de boeken van 1817 , zoodat v. d. Capellen reden had hem te schrijven: „de boekhouding zal ten minste niet onder de schoone zijde vau mijne administratie kunnen gerangrschikt worden."

Nog ééne opmerking, die het IIe stuk geldt, doch onmogelijk noch in den tekst noch in eene noot hare plaats kon vinden. Op blz. 10 haalden wij eene verklaring van J. C. Baud aan. Blijkens de levensschets van den heer Mijer, was Baud aanvankelijk zoer de beginselen van Commissarissen-Generaal toegedaan, - bij verklaart dit zelf (blz. 146) - en dus weinig ingenomen met het stelsel vall den Generaal van den Boseh; doch hij schijnt later bij de uitkomsten, die hij waarnam, geheel van gevoelen voranderd te zijn, en van tegenstander een voorstander van het stelsel te zijn geworden. Baud was toeu werkzaam bij het Dept. van Kolonien, en van den Bosch hield toen voortdurend eene vertrouwelijke briefwisseling met hem. Zoo schreef Baud aan van den Bosch den 4 Juli 1831: "het stelsol van landbouw door Uwe Exc. ingevoerd, zal voorzulier dit is mijus inmige unrtuiging, zegepralen over al de tegenwerkingen, dic nu nog daartegen gemaakt worden.... Het zal niet genoeg zijn,

(*) Baud vertrok uit Inlië in 182L. 
dat do regering het ingevoerde stelsel handhave, als een gewrocht van 's Konings wil; eene zoodanige handlkaving zonder eigen overtuiging is wil haren aurd alloos passief en flaun." Mijer, blz. 368. In eenen brief aan van der Capellen, dd. 30 Aug. 1833, schreef hij: "Vroeger dacht ik dat de belangen van het gouvernement 't best zoude worden bevorderd door aan de inlandsche bevolking de vrije beschikking over tijd en vlijt te laten. Ik meende dat de teelt van voortbrengselen voor de markt van Europa, ondersteund door de vrijwillige belangstelling van vijf millioen menschen eene hoogere vlucht nemen zoude, dan wanneer dezelve op hoog gezaly door een gering aantal ambtenaren aan hen opgedrongen werd. Ik geloofde eindelijk, dat het laiss"r frire, of althans de minst nogelijke bemoeiing van gouvernementswege met de industrie der inlanders, de beste staatkunde was. Dr ondervinding heeft mij deze berfinstlen als dwalingen leeren kennen." Mijer blz. 395, 396. En in 1834 schreef hij aan van den Bosch, dat hij zich had overtuigd, ndat het systema van kultures in zich zelf niets bevatte, dat zich tegen de handhaving en verdere uitbreiding van hetzelve verzette." Ibidem 446. In eene latere periode echter van zijn leven, nl. gedurende zijne parlementaire loopbaan, is hij eenigzins van zijne hooge ingenomenheid voor het kultuurstelse] teruggekomen, en kon hij, schrander staatsman als hij was, het oog niet sluiten voor de zware schaduwzijde er van.

Ten slotte veroorloven $w i j$ ons nog een paar nalezingen. Op blz 27 wordt met betrekking tot de wenschelijkheid om den prijs der koffie naar gelang van den meerderen of minderen arbeid en vau locale omstandigheden te doen verschillen, verwezen naar de conclusie van de commissie in wier handen het verslag der koffieenquête was gesteld. Wij halen hierbij nog aan eene belangrijke nota van den heer C. Castens te vinden in het Verslag der Algemeene Vergaderingen van het Indisch Genootschap 1874 (zie vooral blz. 152). In hetzelfde Verslag vindt men nog twee belangrijke nota's van de heeren A. C. Joosten en Mr. W. K. baron van Dedem. Ook de laatste acht een prijsverschil naar gelang van locale omstandigheden voor niet onmogelijk. Zie blz. 107.

Op blz. 32 wordt gesproken over den invloed, die prijsverhooging op de vrijwillige koffiekultuur kan uitoefenen. Wij verwijzen daarvoor evenzeer naar de nota van den heer Castens, blz. 144. „Eene

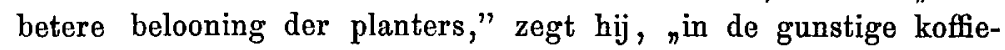
streken moet de hier en daar door neven oorzaken reeds aanwezige 
vịjwillige koffiekultuur meer en meer uithreiding doen erlangen, om daar, waar zij vatbaarheid van bestaan heeft, eene volkskoffie. kultuur de verplichte teelt to zien vervangen. De successieve verhooging is tevens de weg naar de mogelijkheid der opheffing van het koffiemonopolie en hare vervanging door cene belasting".

Last not least. $O p$ blz. 33 wordt besproken de tegenwoordige richting, or van de koffie eeno vrije volkskultuur te maken. Ten einde een buwijs te geven hoe men in Indië de ontwikkeling en aanmoediging van die vrijwillige volkskultuur opvat, strekke het onlangs genomen besluit van den G.-G. dd. 25 Nor. 1878, dat ons ter kennis kwam, nadat wij onze beschouwingen op blz. 33 hadden geschreven. De considerans en het besluit luiden:

„Dat hij, het wenschelijk achtende, de binnen het Gouvernement Sumatra's Westkust (de tot dat gewest behoorende eilanden daaronder niel begrepen) bestaande verplichte koffiekultuur nader te bevestigen.

„Art. 1: „Nalatigheid of onwil van leden der inheemsche bevolking binnen het Gouvernement Sumatra's Westkust in het op den tot dusver gebruikelijken voet aanleggen en onderhouden van koffieplantsoenen en plukken en bereiden der koffievruchten wordt gestraft met eene geldboete van $f 1$ tot $f 15$, en bij wanbetaling met ten arbeidstelling aan de publieke werken voor den kost zonder loon van 1 tot 6 dagen."

L. 
OVERZIGT vin de opbremyst der Rijks-Middelen (hoofdsum en opcenten) over het volle jaar 1878, in vergelijking met de raming voor dat jaar, en de opbrengst over vorige jaren.

\begin{tabular}{|c|c|c|c|c|c|c|c|}
\hline $\begin{array}{c}\text { BEN A I ING } \\
\text { DER } \\
\text { M ID DELEN. }\end{array}$ & $\begin{array}{l}\text { BEDRAG } \\
\text { der } \\
\text { Laming } \\
1878 .\end{array}$ & $\begin{array}{l}\text { Opbrengst } \\
\text { over de } \\
\text { twanli } \\
\text { paausden } \\
\text { van } 1878 .\end{array}$ & $\begin{array}{c}\text { Opbrengst } \\
\text { over de } \\
\text { twaalf } \\
\text { maanden } \\
\text { yau } 1877 .\end{array}$ & $\begin{array}{l}\text { Opbrengst } \\
\text { over de } \\
\text { twaalf } \\
\text { maanden } \\
\text { van } 1876 .\end{array}$ & $\begin{array}{l}\text { Opbrengst } \\
\text { over de } \\
\text { twailf } \\
\text { maanden } \\
\text { van } 1875 .\end{array}$ & $\begin{array}{l}\text { Ophrengst } \\
\text { over de } \\
\text { twaalf } \\
\text { maunden } \\
\text { vau } 1874 .\end{array}$ & $\begin{array}{l}\text { Opbrengst } \\
\text { over de } \\
\text { twaalf } \\
\text { manpden } \\
\text { van } 1873 \text {. }\end{array}$ \\
\hline 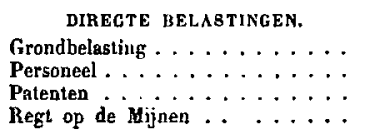 & $\begin{array}{r}10.541 .223 \\
9.318 .000 \\
3.852 .800 \\
3.585 \\
\end{array}$ & $\begin{array}{r}10.573 .208 \\
9.405 .275 \\
4.028 .101 \\
2,398 \\
\end{array}$ & $\begin{array}{r}10.5202 .55 \\
9.170 .564 \\
3.912 .172 \\
3.556\end{array}$ & $\begin{array}{r}10.464 .778 \\
8.404 .610 \\
3.843869 \\
4.088\end{array}$ & $\begin{array}{r}10.421 .433 \\
8.776975 \\
3.965 .915 \\
4.060 \\
\end{array}$ & $\begin{array}{r}10.351 .934 \\
8.588 .503 \\
3687.842 \\
B .614 \\
\end{array}$ & $\begin{array}{r}10,334.794 \\
8.424 .702 \\
3.626 .230 \\
3.961 \\
\end{array}$ \\
\hline Totaal .... & 23.715 .588 & 24008.984 & 25.606 .148 & 29.217 .946 & 88168.394 & 22.684 .895 & 22.389 .629 \\
\hline $\begin{array}{l}\text { IN- UITGaANDE REgTeN. } \\
\text { Regten op den In- en Uit voer } \ldots \\
\text { Formaat-zegel. } \\
\text { Vuur- Ton- en Bak engelden } \ldots\end{array}$ & $\begin{array}{c}4.600 .000 \\
11.040 \\
" 1\end{array}$ & $\begin{array}{c}4572.634 \\
10.677 \\
\pi\end{array}$ & $\begin{array}{c}5.120 .520 \\
12.250 \\
\cdots\end{array}$ & $\begin{array}{c}5.789 .098 \\
18997 \\
\text { " }\end{array}$ & $\begin{array}{r}5.125 .610 \\
19.839 \\
244.956\end{array}$ & $\begin{array}{r}5.293 .260 \\
13.997 \\
541.993 \\
\end{array}$ & $\begin{array}{r}5.228 .875 \\
14.035 \\
538.021\end{array}$ \\
\hline Totaal . . . . & $4.611 .04 ?$ & 4.589 .312 & 5.192 .771 & 5.803 .095 & 5.684 .405 & 5.849 .251 & 5.774 .931 \\
\hline 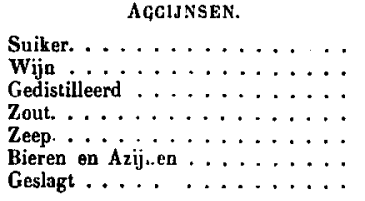 & $\begin{array}{r}6000.000 \\
1,950.000 \\
22.116 .000 \\
3.000 .000 \\
1.520 .000 \\
870.000 \\
2.475000\end{array}$ & $\begin{array}{r}6.490 .946 \\
2074.134 \\
22.031 .358 \\
9.157 .239 \\
1.633 .977 \\
913.720 \\
2.67 \times .045\end{array}$ & $\begin{array}{r}6.133 .066 \\
2.056 .117 \\
21.095 .760 \\
3147.204 \\
1.579 .543 \\
926.227 \\
2.732 .086\end{array}$ & $\begin{array}{r}6.353 .900 \\
1.978 .356 \\
20.049 .834 \\
3.068 .292 \\
1.568 .172 \\
895.969 \\
2.754 .103\end{array}$ & $\begin{array}{r}5.737 .224 \\
1.844 .832 \\
18.706 .786 \\
3.022281 \\
1.542 .431 \\
.869 .524 \\
2.548 .545\end{array}$ & $\begin{array}{r}5.117 .309 \\
1.821 .178 \\
17.401 .967 \\
3.011 .953 \\
1.469 .439 \\
848619 \\
2.404 .296\end{array}$ & $\begin{array}{r}5.399 .314 \\
1.808 .417 \\
17.107 .231 \\
2.962 .577 \\
1.436 .848 \\
863.843 \\
\mathbf{2 . 3 9 7 . 6 8 1}\end{array}$ \\
\hline Totaal $\ldots \ldots$ & 37.931 .000 & 38.979 .422 & 87.670 .012 & 36.662 .629 & 94.271 .877 & 32634.764 & 31.975.408 \\
\hline $\begin{array}{l}\text { WAARBORG EN BELASTING DER } \\
\text { GOUDEN EN ZILYEREN WERKEN. }\end{array}$ & & & & & & & \\
\hline $\begin{array}{l}\text { Belasting } \ldots \ldots \ldots \ldots \ldots \ldots \\
\text { Essagiloon. } \ldots \ldots \ldots \ldots \ldots \ldots\end{array}$ & $\begin{array}{r}365.000 \\
1.200\end{array}$ & $\begin{array}{r}864.116 \\
1.172\end{array}$ & $\begin{array}{r}380.859 \\
1.142\end{array}$ & $\begin{array}{r}373145 \\
1.211 \\
\end{array}$ & $\begin{array}{r}375.548 \\
1.134 \\
\end{array}$ & $\begin{array}{r}363.268 \\
1.282\end{array}$ & $\begin{array}{r}361.627 \\
1.188\end{array}$ \\
\hline Totral. . . & 366.200 & 365.288 & 382.001 & 374.357 & 376.683 & 384501 & 362.815 \\
\hline 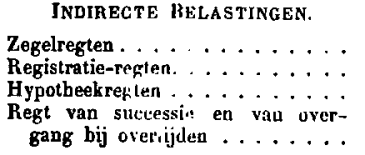 & $\begin{array}{r}2.070 .000 \\
10.350 .000 \\
1.035 .000 \\
6.900 .000\end{array}$ & $\begin{array}{r}2.109 .761 \\
10.675 .447 \\
1.047816 \\
6.607344\end{array}$ & $\begin{array}{r}2.192 .213 \\
11,269.529 \\
1.049 .594 \\
6.196 .593\end{array}$ & $\begin{array}{r}2117.858 \\
11.109 .879 \\
1.066 .843 \\
8.49 .669\end{array}$ & $\begin{array}{r}2.119 .492 \\
10.272498 \\
995.308 \\
7.831 .954\end{array}$ & $\begin{array}{r}2.011 .293 \\
9.637 .797 \\
921.973 \\
8.335 .966\end{array}$ & $\begin{array}{r}2.030 .387 \\
9.655 .970 \\
935.184 \\
\\
5.191 .085\end{array}$ \\
\hline Totaal .... & 20.855 .000 & 20.440 .370 & 20.640 .925 & 22.544 .850 & 21.219 .253 & 20.907 .030 & 17.812 .626 \\
\hline Domeinen. . . . . . & 1.740 .000 & 1.574 .774 & 1.615 .094 & 1.594 .654 & 1.461 .243 & 1.479 .887 & 1.421 .027 \\
\hline Posterijen . . . . . . . . . . & 3.400 .000 & 3.631 .004 & 3.4160 .740 & 3.332 .422 & 3.018 .114 & 2.751 .125 & 2.798 .188 \\
\hline Rijkstelegraphen . . . & 800.000 & 821.485 & 788.417 & 783.343 & 718.486 & 685.797 & 671.955 \\
\hline Staatsloterij. . & 430.000 & 433.755 & 433.607 & 433.995 & 433.381 & 414.109 & 414.090 \\
\hline Acten voor de jagl en visscherij .. & 140,000 & 150.414 & 146.692 & 143.434 & 140.378 & 136.119 & 135.660 \\
\hline Loodsgelden. . . . . & 900.000 & 920.956 & 906.505 & 921.729 & 882.308 & 951.944 & 1.025 .132 \\
\hline Tulaal generval ... & .888.828 & 95.909767 & 94.783 .255 & 95.811 .257 & 91.374 .526 & 88.803 .427 & 84.781 .466 \\
\hline
\end{tabular}

